\title{
Historical tsunamis and present tsunami hazard in eastern Indonesia and the southern Philippines
}

\author{
Finn Løvholt, ${ }^{1}$ Daniela Kühn, ${ }^{2}$ Hilmar Bungum, ${ }^{2}$ Carl B. Harbitz, ${ }^{1}$ and Sylfest Glimsdal ${ }^{1,2}$ \\ Received 3 May 2012; revised 7 August 2012; accepted 14 August 2012; published 22 September 2012.
}

[1] Eastern Indonesia and the southern Philippines comprise a huge and seismically highly active region that has received less than the deserved attention in tsunami research compared with the surrounding areas exposed to the major subduction zones. In an effort to redress the balance the tsunami hazard in this region is studied by establishing a tsunami event database which, in combination with seismological and tectonic information from the region, has allowed us to define and justify a number of 'credible worst-case' tsunami scenarios. These scenarios have been used in numerical simulations of tsunami generation and propagation to study maximum water level along potentially affected shorelines. The scenarios have in turn been combined to provide regional tsunami hazard maps. In many cases the simulations indicate that the maximum water level may exceed $10 \mathrm{~m}$ locally and even reach above $20 \mathrm{~m}$ in the vicinity of the source, which is of the same order as what is forecasted along the Sumatra and Java trenches for comparable return periods. For sections of coastlines close to a source, a tsunami may strike only a few minutes after it is generated, providing little time for warning. Moreover, several of the affected areas are highly populated and are therefore also high risk areas. The combination of high maximum water levels, short warning times, dense populations, and relatively short return periods suggests strongly that the tsunami hazard and risk in these regions are alarmingly high.

Citation: Løvholt, F., D. Kühn, H. Bungum, C. B. Harbitz, and S. Glimsdal (2012), Historical tsunamis and present tsunami hazard in eastern Indonesia and the southern Philippines, J. Geophys. Res., 117, B09310, doi:10.1029/2012JB009425.

\section{Introduction}

[2] Even though tsunami disasters are part of human history, the December 26, 2004, Indian Ocean tsunami represents a landmark in several ways, with more than 220,000 fatalities (http:/www.emdat.be). This tsunami was followed by an earthquake and tsunami of similar strength hitting Japan 11 March 2011, but the latter claimed fatalities of about an order of magnitude less than the 2004 event, most likely due to better warning systems and tsunami awareness. The 2004 earthquake had a moment magnitude of 9.1-9.3 and a rupture length of about $1200 \mathrm{~km}$ [Lay et al., 2005; Ammon et al., 2005; Titov et al., 2005]. With an estimated return period of at least several hundred years [Løvholt et al., 2006], the tsunami struck a population that was without any societal memory of such disasters, and therefore largely unprepared. Every year following the disaster there have been large earthquakes in several regions in Indonesia ranging from Sumatra in the West to Sulawesi, Buru Island, and New Guinea in the East. The USGS has reported more than 30 'significant earthquakes' (mostly above magnitude

\footnotetext{
${ }^{1}$ NGI, Oslo, Norway.

${ }^{2}$ NORSAR, Kjeller, Norway.

Corresponding author: F. Løvholt, NGI, PO Box 3930, NO-0806 Ullevål Stadion, Oslo, Norway. (finn.lovholt@ngi.no)

C2012. American Geophysical Union. All Rights Reserved. 0148-0227/12/2012JB009425
}

6) for Indonesia during the four years following this megathrust event, providing repeating evidence of the persisting significant earthquake potential within this region [e.g., McCloskey et al., 2010].

[3] Since then, major efforts have been invested into developing Tsunami Early Warning Systems (TEWS) [e.g., Bernard et al., 2006; Rudloff et al., 2009; Behrens et al., 2010; Lauterjung et al., 2010; Falck et al., 2010; Roessler et al., 2010], but also into physical mitigation structures, as well as into extensive scientific studies and practical efforts ranging from international to local levels. A significant amount of work has been put into tsunami modeling as well as hazard and risk assessment, in particular toward western Sumatra and Java [e.g., Borrero et al., 2006; Sengara et al., 2008; Okal and Synolakis, 2008; McCloskey et al.; 2008; Post et al., 2009; Brune et al., 2010; Spahn et al., 2010; Gayer et al., 2010; Okal et al., 2011; Blaser et al., 2012] and the western coast of Thailand [e.g., Løvholt et al., 2006; Römer et al., 2010; Kaiser et al., 2011]. Paleotsunami field investigations have further indicated evidence of prehistoric disasters [e.g., Jankaew et al., 2008; Monecke et al., 2008].

[4] However, less attention has been given earlier to the large regions of South East Asia where tsunami hazard and risk are also high, as is easily seen from simple overviews of past disasters [e.g., Hamzah et al., 2000; Okal et al., 2011]. Hence, the present study is concentrated on the large and heavily populated region shown in Figure 1. Due to the complexity of the region, tsunami hazard from non-seismic 


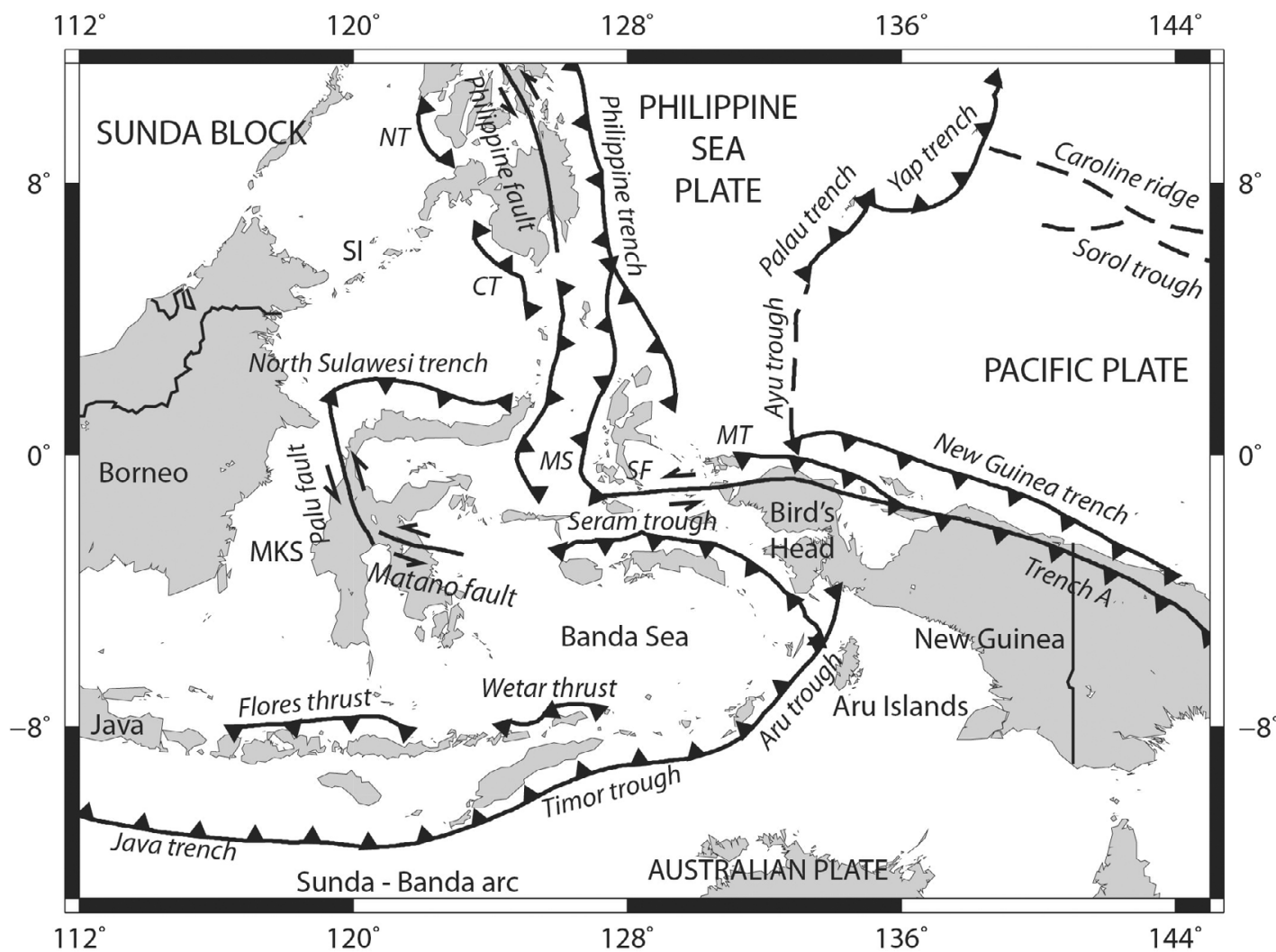

Figure 1. Large-scale overview of the tectonics of eastern Indonesia and the southern Philippines; straight black lines represent transform faults, black lines with triangles indicate trenches (subduction zones), and dashed lines mark ridges; CT: Cotabato trench; MKS: Makassar Strait; MS: Molucca Sea; MT: Manokwari trench; NT: Negros Trench; SF: Sorong fault; SI: Sulu Islands.

sources is not addressed. To identify and define representative scenarios, the regional seismicity is analyzed first, including focal mechanisms and magnitude distributions, as well as regional tectonics (Section 2.1 as well as Sections 3.2-3.3). Subsequently, a regional historic tsunami catalog is established (Section 2.2). Five sub-regions that represent the largest tsunamigenic potentials in the region are selected. The sub-regions are introduced in Section 2, and are selected based on the review of historical earthquakes and tsunamis in Sections 2 and 3. The applied hazard methodology is discussed in Section 3. Furthermore, fault dimensions and slip values are defined in the same section, with scenario moment magnitudes guided by historical events. For these scenarios, tsunami propagation is computed and the maximum water level is estimated by combining tsunami propagation simulations with a wave amplification factor depending on wave and bathymetry characteristics (Section 4.1). Results are presented in Section 4.2 and subsequently summarized into a regional overview that can be interpreted as a first order tsunami hazard map (Section 4.3), demonstrating the tsunamigenic power of the scenarios in the study region.

\section{Seismological and Tsunami Background and Data}

[5] In this section a brief overview on seismicity and tectonics of the study region as well as a tsunami database are presented, both limited to what is required to support the subsequent determination and delineation of the tsunami scenarios, which is the main purpose of this paper.

\subsection{Seismicity and Tectonics of the Study Region}

[6] A large-scale overview of the tectonic settings of the study region is shown in Figure 1, while the seismicity in the different sub-regions is shown in Figure 2. A more detailed overview of geographical names can be found in Figure 7. Kreemer et al. [2000] and The Plates Project (http://www.ig. utexas.edu/research/prjects/plates/) are followed for displaying tectonic features.

[7] The main feature of this tectonically complicated region is the interaction between four tectonic plates that are, in counter-clockwise direction, the Sunda block, the Australian plate, the Pacific plate, and the Philippine Sea plate. In the section of the Sunda-Banda arc from Java to Wetar separating the Sunda block from the Australian plate, the subduction style changes from subduction of old oceanic crust (Indian Ocean) beneath continental margin (Sunda shelf) to subduction of continental crust (Australia) beneath an island arc (Banda arc) built on oceanic crust [McCaffrey and Nábělek, 1987]. Although slab dip, convergence rate, lithospheric age, and maximum earthquake size would place the Java trench in the category of subduction zones with back arc spreading, McCaffrey and Nábělek [1987] argue for back arc compression in this region. Active back arc thrusting occurs 


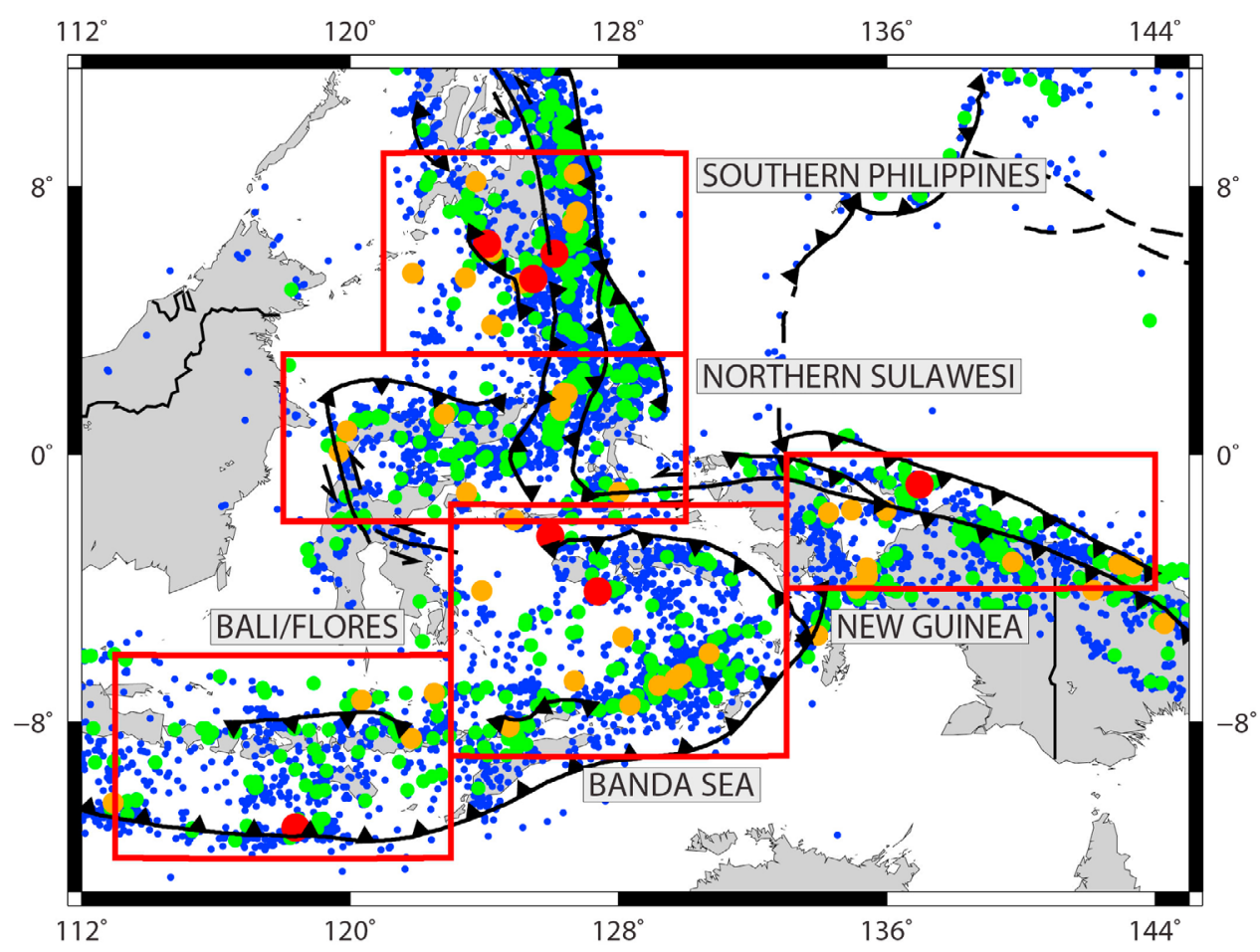

Figure 2. Seismicity in the study region 1963-2006, with symbol colors and sizes corresponding to magnitudes: red dots represent earthquakes above magnitude 8, orange dots earthquakes with magnitudes 7-8, green dots earthquakes with magnitudes 6-7 and blue dots depict smaller events down to magnitude 5 . Red boxes depict sub-regional study areas.

north of Flores [McCaffrey and Nábĕlek, 1984]. Both the Flores and Wetar back arc thrusts are seismically much more active than the subduction thrust fault near the Timor trough, which indicates a jump in the locus of convergence from the Java trench to the back arc east of $118^{\circ}$ [Kreemer et al., 2000; Nugroho et al., 2009] and which may result in a subduction polarity reversal [Hamilton, 1979; Nugroho et al., 2009].

[8] The Timor trough bends NE into the Aru trough and subsequently west into the Seram trough. The structural continuity is controversial [Cardwell and Isacks, 1978; McCaffrey, 1988; Katili, 1989]. Also within the broad area between Timor and Seram troughs, the upper plate is shortened beneath fore and back arc basin due to the collision of the Australian continent with the Banda arc [McCaffrey, 1988]. Moreover, there is no sign for back arc spreading within the Banda basin. Earthquakes suggest the presence of an additional thrust fault south of Ambon and Seram similar to the Flores and Wetar thrust, but with N-NE directed thrusting [McCaffrey, 1988]. New Guinea accommodates the highly oblique convergence between the Pacific and the Australian plates by strain partitioning [Kreemer et al., 2000]. A high level of seismicity is associated with the subduction at the Molucca Sea double subduction zone and with the North Sulawesi trench [Kreemer et al., 2000]. The oblique convergence between Pacific plate and Sunda block in the Philippine region is accommodated by strain partitioning between the near-trench-normal subduction at the Philippine trench and left-lateral-shear motion at the Philippine fault.

[9] The study region as shown in Figure 1 is covering the eastern parts of Indonesia and the southern Philippines. Sub- regional study areas applied in the hazard evaluations below are shown as red boxes in Figure 2, namely Banda Sea, Bali/ Flores, northern Sulawesi, New Guinea, and southern Philippines. The applied earthquake catalog essentially consists of merged hypocenter reports from the International Seismological Centre (ISC) and Preliminary Determination of Epicenters (PDEs) from the U.S. Geological Survey (USGS), both with a good global coverage since the early 1960s. Figure 2 depicts the high level of seismicity recorded from 1963 to 2006, which illustrates that earthquakes above moment magnitude $\mathrm{M}_{\mathrm{w}} 7.0$ occur commonly and that $\mathrm{M}_{\mathrm{w}} \sim 8.0$ occur in all sub-regions. Since magnitudes are indicated only qualitatively in terms of symbol sizes and colors, an overview of the magnitude $\left(\mathrm{M}_{\mathrm{w}}\right)$ distribution for each sub-region is presented in Figure 3. Magnitudes not originally reported in $\mathrm{M}_{\mathrm{w}}$ are converted to $\mathrm{M}_{\mathrm{w}}$ [Okal and Romanowicz, 1994], and a maximum likelihood procedure is employed to compute activity rates and b-values [Musson, 2011; Musson et al., 2011]. To this end, the catalog has been subdivided not only into sub-regions, but also into time periods according to assessed levels (magnitudes) of reporting completeness. Regression of the magnitude distribution in each of the subregions is stable and leads to $b$-values close to 1 , as expected.

\subsection{A Regional Catalog of Historical Tsunamis}

[10] The process of developing a tsunami hazard model is essentially based on understanding past events, and to this end a tsunami catalog for Indonesia and the Philippines is established. The database covers a larger geographical area than the hazard study area displayed in Figure 1, with the source information depicted in Figure 4. This catalog is 


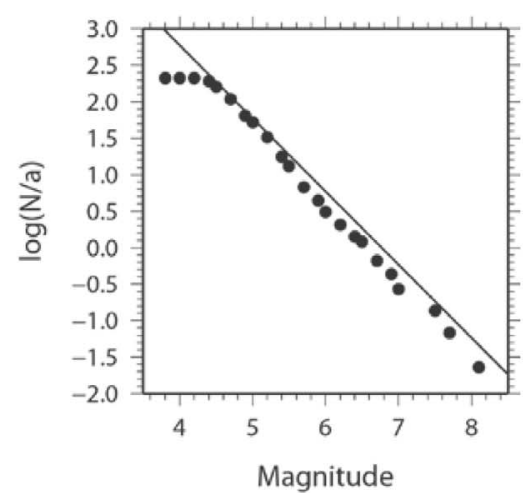

a)

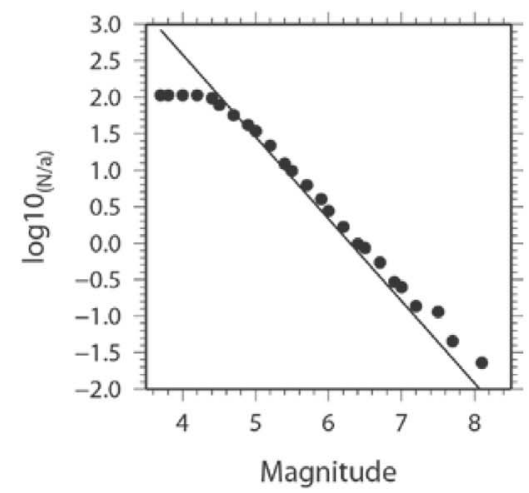

d)

Figure 3. Magnitude distributions 1963-2006 for the five sub-regions shown by red boxes in Figure 2: (a) Banda Sea, (b) Bali/Flores, (c) northern Sulawesi and northern Moluccas, (d) New Guinea, (e) southern Philippines; table gives a- and b-values resulting from maximum likelihood computations [Musson, 2011; Musson et al., 2011].

mainly based on databases of the National Geophysical Data Center (subsequently referred to as NGDC) and the Tsunami Laboratory Novosibirsk (subsequently referred to as TLN), supplemented with papers describing certain events [Imamura et al., 1995; Natawidjaja et al., 2006; Ortiz and Bilham, 2003; Satake and Atwater, 2007]. Compared with an earlier review by Hamzah et al. [2000], the present database is updated, covers a larger geographical area, and includes more events.

[11] For many of these events, the source information is based on recent re-evaluations of locations, focal depths, and magnitudes [Engdahl and Villaseñor, 2002; Engdahl et al., 2007; Villaseñor and Engdahl, 2007; also Engdahl, personal communication, 2007]. The source information is critically reviewed and updated, and obviously erroneous data are removed. This reassessment has led to significant revision of the metadata from the NGDC and TLN databases in some cases, particularly with respect to focal depths. Parameters for recent events were largely reliable, but discrepancies are expected to be prominent for the older events. Except for one incidence (a tsunami occurring in the year 416), all recorded tsunamis occurred in the 17 th century or later. Up to 1825 , the reporting rate was about 7.5 years between each event in average, but from 1825 and up to the present, the rate increased to about 0.85 years between each reported event.

[12] The tsunami data are collated by conducting database queries based on both regional keywords and by specifying that the coordinates of the tsunami sources are located within $15^{\circ} \mathrm{S}-25^{\circ} \mathrm{N}$ and $85^{\circ}-140^{\circ} \mathrm{E}$. Using the database reliability index, tsunamis categorized as erroneous or very doubtful were removed from the queries, whereas data being categorized as questionable, probable, or definite were included, covering $27 \%, 28 \%$ and $45 \%$ of the 249 reports, respectively. The tsunamigenic categories include a number of different sources, e.g., NGDC operates with 12 different categories including among others earthquakes, landslides, and volcanoes, as well as combinations thereof. If sources are categorized as earthquake or probable earthquake they are referred to as earthquakes in the visualization and the statistics. Where combinations of sources are reported, sources are grouped into one of the main categories (landslides or volcanoes) to simplify the visualization. The distribution of reported tsunamis with respect to sources shows that 115 of the reports are related to $M \leq 7.5$ events, 36 to $7.5<\mathrm{M} \leq 8.0,13$ to $8.0<\mathrm{M} \leq 8.5$ and 8 to $\mathrm{M}>8.5$ events. In comparison, 21 reports are related to volcanoes and 9 to landslides. Figure 4 shows the locations of sources indicating the source type as described above. 

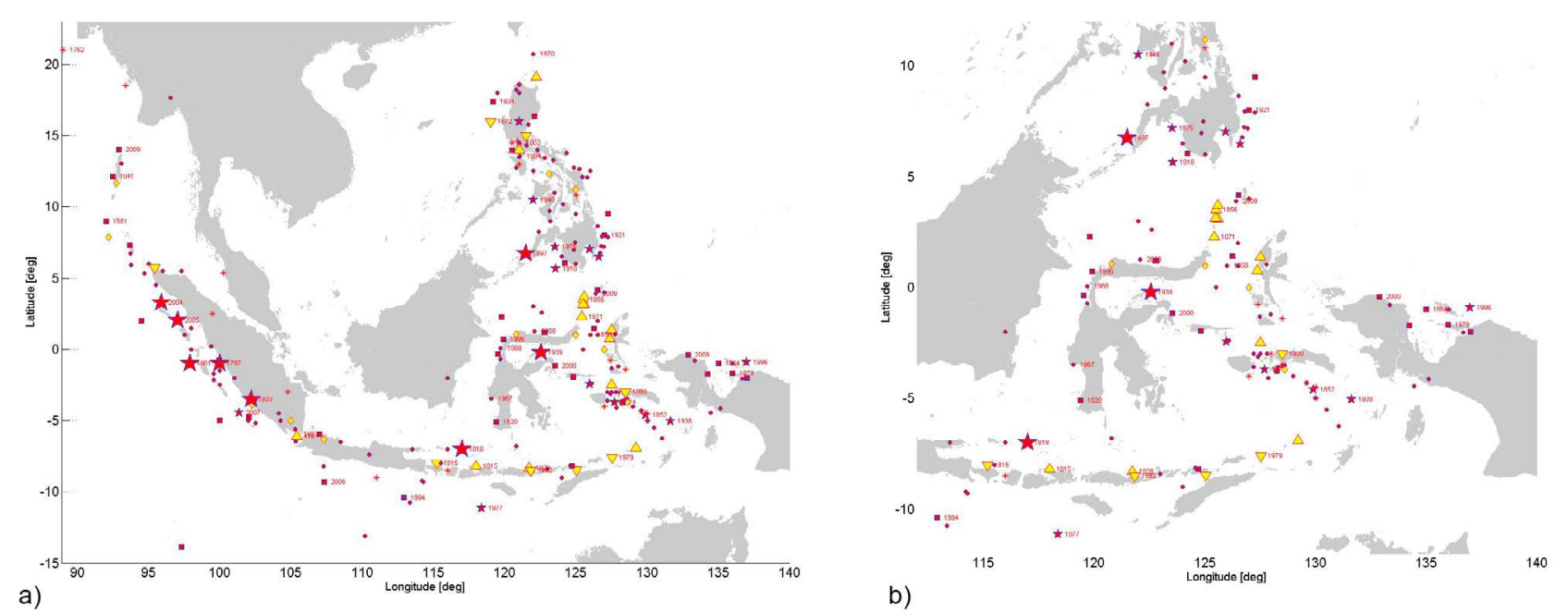

Figure 4. Locations for recorded historical tsunamis in South East Asia including source information. Year of occurrence is indicated for some events. Yellow markers indicate non-seismic or unknown sources, red markers indicate seismic sources. Large stars display magnitudes $\mathrm{M} \geq 8.5$, small stars $8.5>$ $M \geq 8.0$, squares $8.0>M \geq 7.5$, circles $M<7.5$, an asterisk means that no magnitude is reported. Upward-pointing triangles indicate volcanoes or combinations of volcanoes and other sources, and downward-pointing triangles indicate landslides or combined landslides/earthquakes. Diamonds indicate unknown sources. (a) Whole database; (b) study area.

[13] In both the NGDC and the TLN databases, the number of fatalities for each tsunami is reported. The regional distribution of these reports shows that devastating tsunamis have been generated along most of the Sunda arc, in eastern Indonesia and in the Philippines, which gives an important focus on this region, knowing that most efforts on tsunami simulation and warning nowadays focus on western Sumatra and the Java trench. In Table 1, all reported events with 100 and more fatalities are listed. For earthquake-generated tsunamis with magnitudes smaller than magnitude 8.0, it is found that few or no fatalities dominate. A similar trend of the recorded maximum wave heights is seen in Figure 5, indicating that a larger portion of wave heights above $10 \mathrm{~m}$ are generated by large earthquakes.

\section{Tsunami Hazard Methodology and Scenario Descriptions}

\subsection{Methodology}

[14] Tsunami hazard analysis has traditionally been scenario-based [Tinti and Armigliato, 2003; Løvholt et al., 2006; Okal et al., 2006; Okal and Synolakis, 2008; Lorito et al., 2008; Tinti et al., 2008; Tang et al., 2009; Okal et al., 2011]. More recently, however, a Probabilistic Tsunami Hazard Analysis (PTHA) approach has been developed and put to practical use [Annaka et al., 2007; Geist and Parsons, 2006; Thio et al., 2007; González et al., 2009; Blaser et al., 2012]. For earthquakes, the highest tsunami risks are related to large low-probability events that generally carry large uncertainties [Nadim and Glade, 2006; Løvholt et al., 2012a]. The eastern Indonesia and southern Philippines regions are less well studied than the Sunda arc subduction zone, and are simultaneously more complex tectonically (Bird [2003] states that "the region of the Molucca Sea, the Banda Sea, and Irian Jaya [...] has the most complex neotectonics on Earth"). Hence, for the present study region it may still be advisable to use the more robust scenario-based approach, as applying PTHA would imply large epistemic uncertainties related to location, parameterization, and return periods of the scenarios entering the analysis. The "credible worst-case scenario approach' applied here is adopted from Løvholt et al. [2006] and Harbitz et al. [2012], and scenarios are restricted to earthquake sources only. Tsunamis originating from the Indian Ocean south of Java and west of Sumatra are not included in the present analysis and neither are far field sources as they are expected to contribute less to the total risk [see, e.g., Titov et al., 2001; González et al., 2009]. The five sub-regions selected for hazard evaluations shown in Figure 2 cover a large part of the full study region. Figure $4 \mathrm{~b}$ shows that the areas with the highest frequency of historical tsunamis in the whole region are included in the sub-regions.

[15] The scenario earthquakes have been located in regions where historical tsunamis of tectonic origin have occurred in the past, and at places where independent seismotectonic criteria have revealed potentials for strong earthquakes. The historical events in Figure $4 \mathrm{~b}$ are used to interpret both the location and size of the tsunamigenic earthquakes. The earthquake models used in this study are simple, justified by the fact that the tsunami generation is sensitive mostly to first order effects on the source side. In this sense there is an important difference between the levels of detail required for sources used for tsunami hazard as compared to those required for earthquake hazard, where considerably more sophistication is needed.

[16] For each tsunami scenario, the slip on the fault plane is assumed to be piecewise rectangular and also pure dipslip, with rigidity (shear strength) acting as key scaling factor to obtain seismic moment and moment magnitude [Hanks and Kanamori, 1979]. For all shallow scenarios 
Table 1. Historical Tsunamis in Indonesia and the Philippines With More Than 100 Reported Fatalities

\begin{tabular}{|c|c|c|c|c|}
\hline Year & Source & Validity & Region & Fatalities \\
\hline 2004 & M9.3 Earthquake & Definite & NICOBAR ANDAMAN & 297248 \\
\hline 1883 & Volcano & Definite & S. JAVA SEA & 36500 \\
\hline 1976 & M8.1 Earthquake & Definite & SW. MINDANAO & 4000 \\
\hline 1899 & Landslides & Definite & BANDA SEA & 3730 \\
\hline 1674 & M8 Earthquake & Definite & BANDA SEA & 2970 \\
\hline 1992 & Landslides and M7.8 Earthquake & Definite & FLORES SEA & 2200 \\
\hline 1815 & Landslide and M7.5 Earthquake & Probable & BALI SEA & 1200 \\
\hline 1861 & M8.5 Earthquake & Definite & SUMATRA & 1105 \\
\hline 1815 & Volcano & Definite & FLORES SEA & 1000 \\
\hline 1861 & M7 Earthquake & Definite & SUMATRA TRENCH & 750 \\
\hline 2006 & M7.7 Earthquake & Definite & S. JAVA SEA & 664 \\
\hline 1969 & M6.9 Earthquake & Definite & MAKASSAR STRAIT & 600 \\
\hline 1930 & M7.2 Earthquake & Definite & MYANMAR COAST & 550 \\
\hline 1979 & Landslide & Definite & FLORES SEA & 539 \\
\hline 1820 & M7.5 Earthquake & Definite & FLORES SEA & 500 \\
\hline 1925 & M6.8 Earthquake & Questionable & W. LUZON ISLAND & 428 \\
\hline 1871 & Volcano, Earthquake, and Landslide & Definite & CELEBES SEA & 400 \\
\hline 1907 & M7.5 Earthquake & Definite & SUMATRA & 400 \\
\hline 1968 & M7.3 Earthquake & Definite & MAKASSAR STRAIT & 392 \\
\hline 1797 & M8.6 Earthquake & Definite & SUMATRA TRENCH & 300 \\
\hline 1863 & M6.5 Earthquake & Probable & W. LUZON ISLAND & 300 \\
\hline 1864 & M7.8 Earthquake & Probable & IRIAN JAYA & 250 \\
\hline 1994 & M7.8 Earthquake & Definite & S. JAVA SEA & 250 \\
\hline 1909 & M7.2 Earthquake & Questionable & SUMATRA TRENCH & 200 \\
\hline 1977 & M8.3 Earthquake & Definite & S. JAVA SEA & 189 \\
\hline 1928 & Volcano and Landslide & Definite & FLORES SEA & 128 \\
\hline 1996 & M8.2 Earthquake & Definite & IRIAN JAYA & 110 \\
\hline 1918 & M8.2 Earthquake & Definite & SW. MINDANAO & 102 \\
\hline 1856 & Volcano & Definite & CELEBES SEA & 100 \\
\hline 1897 & M8.5 Earthquake & Definite & SULU SEA & 100 \\
\hline 1979 & M7.5 Earthquake & Definite & IRIAN JAYA & 100 \\
\hline 416 & Volcano & Questionable & S.JAVA & $101-1000$ \\
\hline 1858 & M7.4 Earthquake & Probable & N. MOLUCCAS & $101-1000$ \\
\hline
\end{tabular}

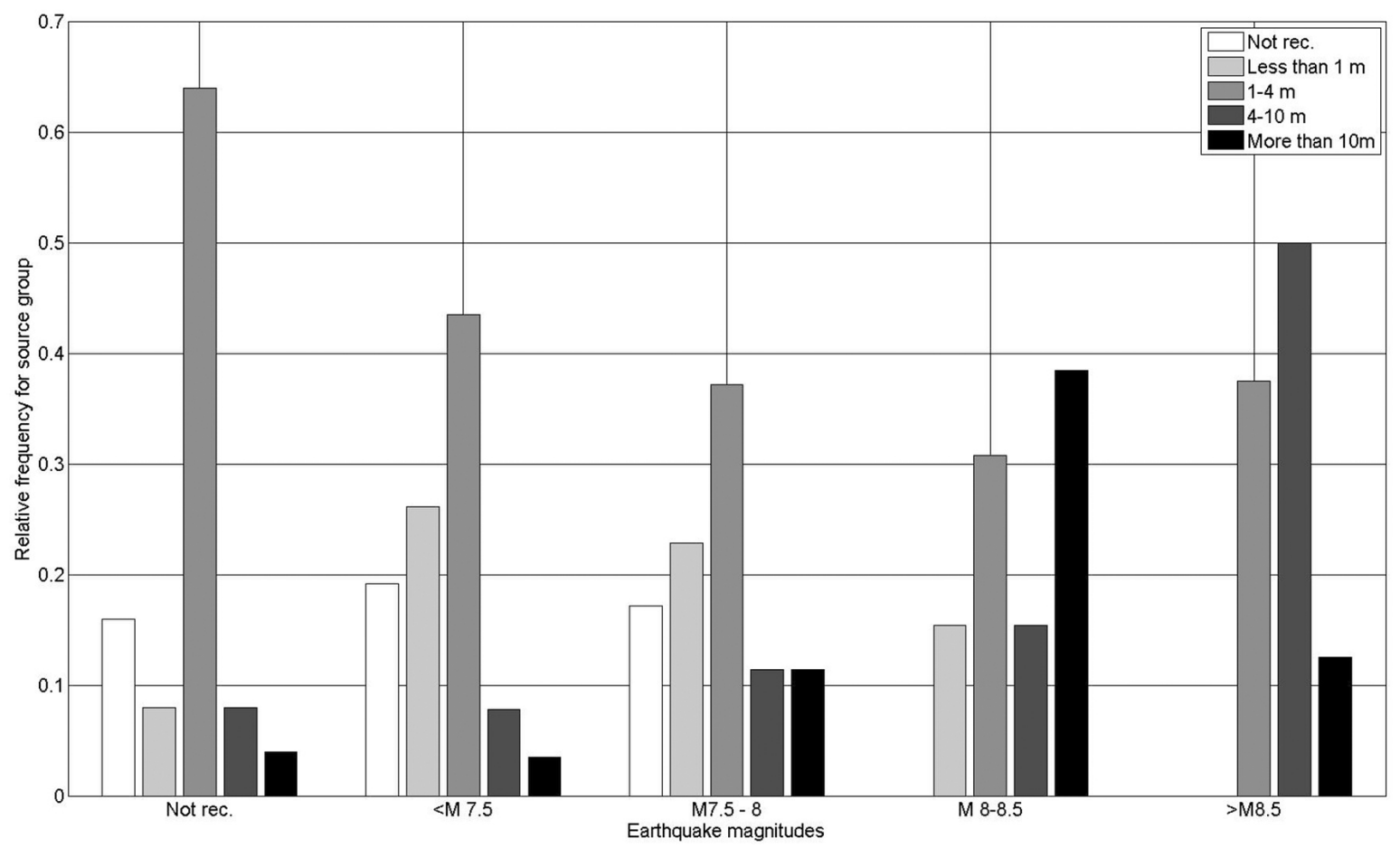

Figure 5. Distribution of tsunamigenic earthquake magnitudes (scaled with the total number of events within each magnitude) combined with reported numbers for the maximum or deduced maximum wave heights. 
along the eastern Sunda arc, relatively low shear stiffness is applied consistent with the findings of Tsuji et al. [1995], Fujii and Satake [2006], Ammon et al. [2006], and Bilek and Engdahl, [2007]. For the scenarios, fault dimensions and slip values were selected such that the resulting earthquake magnitude (roughly complying with scaling relations such as Wells and Coppersmith [1994], Blaser et al. [2010], and Leonard [2010]) is of the same order as the largest historical events (see, e.g., Figure 3), deviating by no more than 0.1 from the largest observed moment magnitude for tsunamigenic earthquakes in each sub-region (neglecting very deep earthquakes). It is noted that although the areas mostly are dominated by smaller fault zones, there are two major subduction zones present in the study area (the New Guinea and Philippine trenches). On the basis of the recent events in 2004 and 2011, the possibility of megathrust events in these subduction zones should not be completely ruled out (see, e.g., Stein and Okal [2007] for a discussion). However, in order to derive scenarios with regionally similar occurrence rates, such extreme low-probability events are not considered in this paper.

[17] The procedure for defining the fault planes is exemplified in Figure 6 for the Banda Sea study region; the subregion with the highest number of historical tsunamis. Figure 6a shows focal solutions from the CMT catalog color-coded according to magnitude. Focal mechanisms vary strongly, also within short distances. Figure $6 \mathrm{~b}$ indicates source locations of the historical tsunamis, using filled circles to visualize the maximum water levels. Although the tsunami catalog contains a variety of events for this region, only four could be identified in the CMT catalog (focal solutions are shown for those events). Figures $6 \mathrm{c}$ and $6 \mathrm{~d}$ present an overview on the seismicity for a depth scale up to $700 \mathrm{~km}$ and $60 \mathrm{~km}$, respectively. The subduction zone is clearly recognizable at greater depths (Figure 6c) whereas seismicity at shallower depths is more diffuse (Figure 6d). Figure 6d displays regional fault lines (green lines on top) and the chosen fault planes in addition. Since it proved difficult to find stable regional trends in the dip of fault planes inferred from the Harvard CMT catalog, the fault planes are instead aligned to patterns discernible from the regional seismicity. The large variation in focal mechanisms is likely to be caused by the tectonic complexity. If not mentioned otherwise, faults were assumed to reach the seafloor. Figure 6e finally shows the initial water displacement resulting from the chosen fault parameters. By inspecting the source locations from the scenarios in Figure 6e, we see that they overlap with the main part of the source positions of the historical events in Figure 6b. A similar procedure is adopted for the other sub-regions, and the choices of earthquake scenarios for each of the selected sub-regions are justified further below. Table 2 summarizes the scenario parameterizations. Figure 7 displays tectonic features and place names and Figure 8 shows an overview of the scenario distribution in terms of initial surface elevation.

\subsection{Scenario Return Periods}

[18] The few plate motion rates in the review of Bird [2003] are of the order of 10 to $30 \mathrm{~mm} / \mathrm{year}$, and are compared with scenario displacements of the order of 3 to $10 \mathrm{~m}$, which indicates return periods of 100 to 1000 years. Extreme lower-bound values of return periods derived from regional Gutenberg-Richter relations (Figure 3) range from about 20 to 120 years. The individual scenarios given below however, are expected to have return periods significantly longer than these lower bound values and to be more consistent with those inferred from plate motion rates, since each of the areas covers more than one scenario and contains additional seismicity not associated with the faults on which the scenarios are located. The independent estimates of return periods from seismicity and plate motions are therefore quite consistent, indicating values of the order of 100 years or more for each of the modeled fault zones. By choosing the moment magnitude close to the maximum historical earthquake, a relatively coherent approach in terms of return periods is obtained, particularly given the large uncertainty. Finally, it is noted that inferring return periods from seismicity is challenging since historic seismic catalogs are too short. Ideally, they should be several times longer than the typical scenario return period.

\subsection{Scenario Description for Each Sub-region}

\subsubsection{Banda Sea}

[19] The Banda Sea region (Figure 7a) is characterized by two different subduction systems: the Java trench - Timor trough - Aru trough system in the south and southeast and the Seram trough subduction zone to the north (Figure 1). The Java trench and Timor trough, as well as the Aru Islands further east, are largely aseismic [Cardwell and Isacks, 1978; Hamilton, 1979], while the Aru Basin shows shallow seismicity. Within the Weber Basin (Figure 7a), deeper hypocenters are interpreted by McCaffrey [1988] as expressing both northward subduction under the Timor-Tanimbar arc in the south, and southward subduction under Seram and Ambon arc to the north. The great Banda Sea earthquake on 1st February 1938 took place on the eastern boundary of the Weber Basin and has one of the 10 largest seismic moments ever computed [Okal and Reymond, 2003], but at the same time had a large focal depth and thus did not produce a significant tsunami. The Wetar back arc thrust north of Wetar and Alor is separated in an eastern and a western part by the northeast trending left-lateral Wetar-Atauro fault [Breen and Silver, 1989] and is associated with seismicity [Cardwell et al., 1981; McCaffrey and Nábělek, 1984] and thrust earthquakes [McCaffrey et al., 1985; Kreemer et al., 2000].

[20] The scenarios for the Banda Sea region are shown in Figures 6 and 8. One scenario is placed north of Buru Island at the Seram trough in an area with several historical tsunamis (reported events in 1657, 1708, 1876, and 1965). Similarly, the second one is located along the thrust fault south of Ambon; historical events constitute among others a major event in 1674 as well as events in 1950 and 1983. A third scenario composited of three fault planes (to represent a curved rupture) is located in the Weber Basin nearby the origin of the historic 1852 tsunami. The fourth scenario is located along the eastern Wetar thrust south in the Banda Sea with a magnitude similar to a reported event in 2004. A comparison of Figures $6 \mathrm{~b}$ and $6 \mathrm{e}$ reveal that the locations of the four scenarios overlap with previous sources found in the tsunami catalog. The scenario magnitudes are slightly larger 

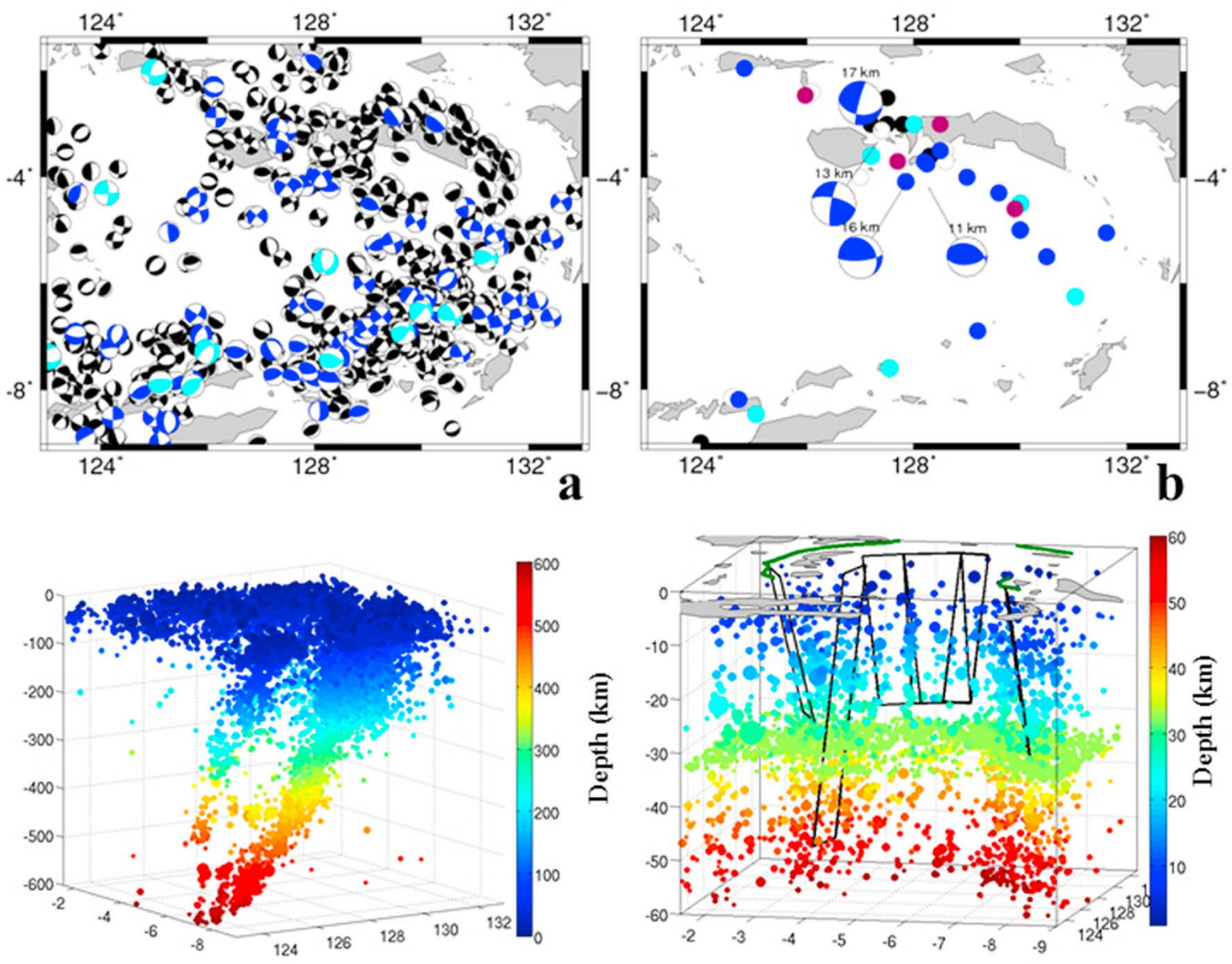

C

d
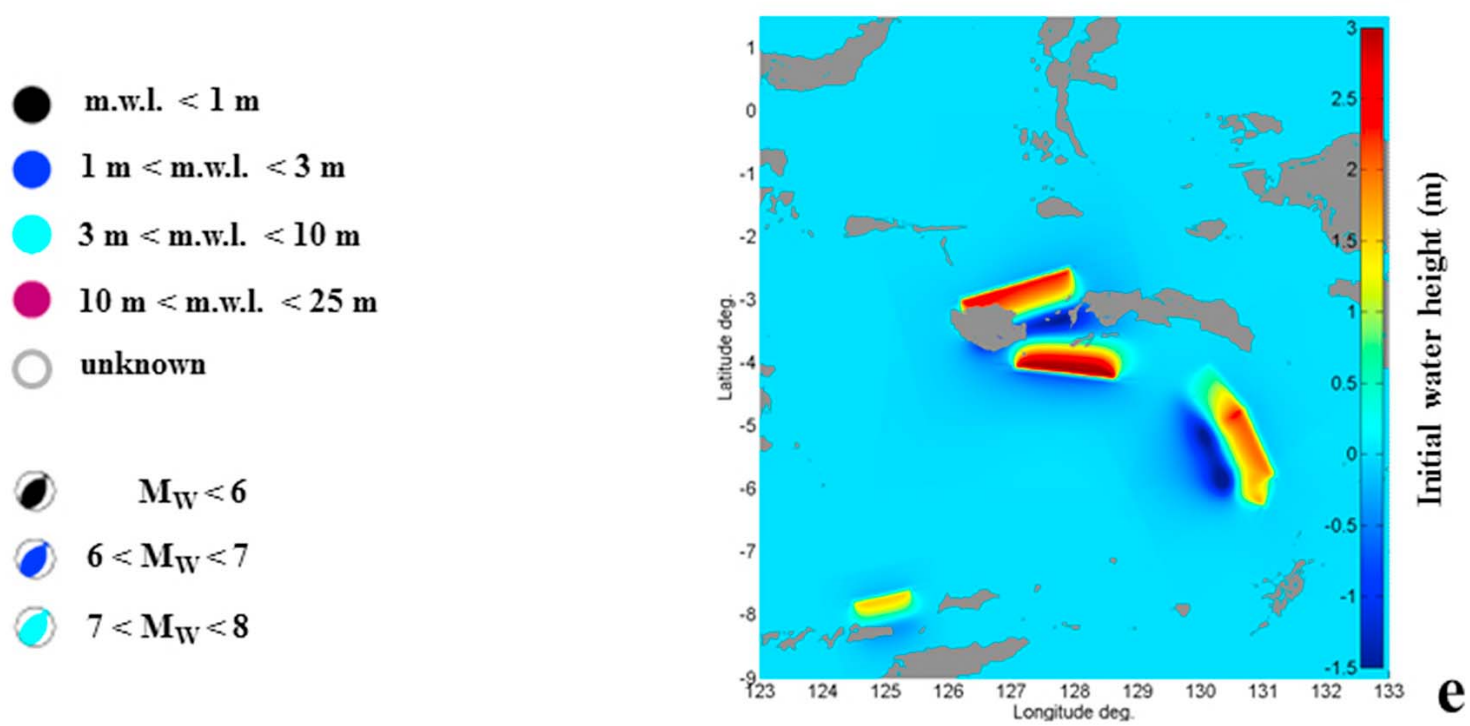

Figure 6. Construction of tsunami scenarios for the Banda Sea region: (a) focal mechanisms for earthquakes in the CMT catalog within time range 1963-2006 (color coding lower left); (b) filled circles: tsunami maximum runup heights (color coding lower left), earthquakes from CMT catalog identified as source for these tsunamis indicated by their focal mechanism; (c) earthquakes from combined catalog, subduction zone clearly visible (color coding according to depth); (d) earthquakes from combined catalog up to depth of $60 \mathrm{~km}$ (color coding according to depth), including location of faults; (e) initial surface elevation. 
Table 2. Earthquake Scenario Parameters ${ }^{\mathrm{a}}$

\begin{tabular}{|c|c|c|c|c|c|c|c|c|}
\hline Location & Region & $\mathrm{L}(\mathrm{km})$ & $\mathrm{W}(\mathrm{km})$ & $\mathrm{D}(\mathrm{m})$ & $\mu(\mathrm{GPa})$ & $\mathrm{H}_{\min }(\mathrm{km})$ & $\theta(\mathrm{deg})$ & $\mathrm{M}_{\mathrm{w}}$ \\
\hline Bali/Lombok & Bali / Flores Seas & 155 & 80 & 5.5 & 10 & 0 & 30 & 7.8 \\
\hline Flores & & 153 & 80 & 5.5 & 10 & 0 & 30 & 7.8 \\
\hline Buru and Ceram & & 202 & 80 & 8 & 20 & 0 & 20 & 8.2 \\
\hline Weber Basin & Banda Sea & 303 & 80 & $5.6^{*}$ & 15 & 0 & 20 & 8.1 \\
\hline Ambon Island & & 179 & 80 & 7 & 15 & 0 & 40 & 8.1 \\
\hline Wetar Island & & 105 & 55 & 4 & 10 & 0 & 30 & 7.5 \\
\hline Eastern Minahassa & Northern Sulawesi and & 184 & 80 & 6.5 & 10 & 0 & 25 & 7.9 \\
\hline Western Minahassa & northern Moluccas & 179 & 80 & 6.5 & 10 & 20 & 25 & 7.9 \\
\hline Sangihe double subduction & & 178 & 70 & 6 & 10 & 0 & 80 & 7.8 \\
\hline Biak Island & New Guinea & 193 & 75 & 8.2 & 30 & 0 & 20 & 8.3 \\
\hline Eastern Irian Jaya & & 193 & 75 & 8.2 & 30 & 0 & 20 & 8.3 \\
\hline Papua New Guinea & & 193 & 75 & 8.2 & 30 & 0 & 20 & 8.3 \\
\hline Cotabato Trench & Southern Philippines & 170 & 80 & $3.4^{*}$ & 30 & 0 & 22 & 8.2 \\
\hline Philippine Trench S & & 176 & 100 & 10 & 30 & 0 & 20 & 8.4 \\
\hline Philippine Trench $\mathrm{N}$ & & 166 & 100 & 10 & 30 & 0 & 20 & 8.4 \\
\hline
\end{tabular}

${ }^{\text {a }} L, W$ and $D$ are fault length, width and slip, respectively; $\mu$ is rigidity (shear modulus); $H_{\min }$ is the minimum fault depth (* indicates a segmented fault, with the mean value of the slip reported); $\theta$ is dip angle; $M_{w}$ is moment magnitude.

than the largest observed magnitudes from the seismic and tsunami catalogs.

\subsubsection{Bali/Flores}

[21] The prominent tectonic features of the Bali/Flores region (Figure 7b) are the Java trench as well as the Flores thrust. The Flores thrust is much more active seismically than the subduction thrust fault near the Timor trough [Kreemer et al., 2000]. The Flores earthquake December 23, 1970, showed active back arc thrusting behind the eastern Sunda arc north of Flores [McCaffrey and Nábĕlek, 1984]. McCaffrey and Nábělek [1987] analyze source mechanisms of eight large earthquakes north of Bali and find mainly thrust mechanisms. The depths of those earthquakes are between 9 and $18 \mathrm{~km}$ and the fault plane dip of six of those earthquakes varies between $25^{\circ}$ and $35^{\circ}$.

[22] The strongest of the historical tsunami events in this region are reported to be caused by combinations of landslides and earthquakes. The earthquake scenarios defined for this region are partly based on the location of historical events, and partly on regional seismicity (Figure 8). For the modeling, two shallow fault planes both belonging to the Flores thrust were chosen, one situated north of Bali and Lombok and the other one located north of Flores (Table 2). The dips of the fault planes are about $30^{\circ}$, matching the 1992 Flores earthquake. The moment magnitude of both scenario earthquakes is 7.8, the same as the 1992 event [Yeh et al., 1995].

\subsubsection{Northern Sulawesi and Northern Moluccas}

[23] The South East Asia triple junction (of trench-trenchfault type) is a primary example of collision accommodated by crustal block rotation instead of mountain building [Socquet et al., 2006]. A number of crustal blocks take part in this rotation, the Makassar block in SW Sulawesi, the North Sula block, the Manado block and the East Sula block in NE Sulawesi (Figure 7c). Walpersdorf et al. [1998] indicate a location of plate intersection in the southern Molucca Sea (represented by a star in Figure 7c), although the convergence area has a $500 \mathrm{~km}$ diameter in total [Vigny et al., 2002].

[24] As scenarios, two fault planes at the North Sulawesi trench are chosen, the first one northeast of the Minahassa peninsula and the second one northwest of Gorontalo, both located in areas with high local seismicity (see Table 2 and Figure 8). Since the seismicity is low at shallow depths north of Gorontalo, the fault plane is placed at a depth of $20-54 \mathrm{~km}$. It was found that a $\mathrm{M}_{\mathrm{w}} 7.9$ earthquake represents a 'credible worst-case scenario' for the area north of the Minahassa peninsula to equal the magnitude of the 1996 event [Pelinovsky et al., 1997], which is the largest tsunamigenic event at the North Sulawesi trench. A third scenario is located in a region of high local seismicity between the East Sangihe fault and the West Halmahera trough, having a moment magnitude of 7.8. From Figures 2 and 4 it is clearly seen that the seismicity is high in this region, and that there is an apparent clustering of past events at the scenario location. Although intermediate depth earthquakes are observed beneath Sangihe and Halmahera arc, the majority of earthquakes occurs at shallow depth (less than $60 \mathrm{~km}$ ) beneath the central part of the collision zone suggesting that convergence between arcs is obtained by shortening within the basement of the Molucca Sea plate leading to high-angle reverse faulting rather than by slip along shallow dipping planes between arcs and subducting slabs [McCaffrey, 1982].

\subsubsection{New Guinea}

[25] Recent tsunamigenic events in this region include the $\mathrm{M}_{\mathrm{w}} 8.21996$ Biak Island tsunami [Matsutomi et al., 2001], the 1998 Papua New Guinea (PNG) tsunami [Heinrich et al., 2000; Bardet et al., 2003; Imamura and Hashi, 2003], and the smaller 2002 [Okal and Synolakis, 2004] and 2010 PNG tsunamis. Whereas the 1996 and 2002 events were of purely seismic origin, the destructive effect of the 1998 PNG tsunami was due to slumping [Tappin et al., 2008]. Only a few earthquakes within this region have a focal depth larger than $150 \mathrm{~km}$.

[26] Three scenarios at the New Guinea trench shifted along the coastline (Figure 8) are proposed, the westernmost scenario being situated near Biak Island, the middle and easternmost ones located north of Irian Jaya (the Indonesian part of New Guinea, see Figure 7d for place names). It was found that an $\mathrm{M}_{\mathrm{w}} 8.3$ earthquake represents a "credible worst-case scenario' for this area. This magnitude is slightly 

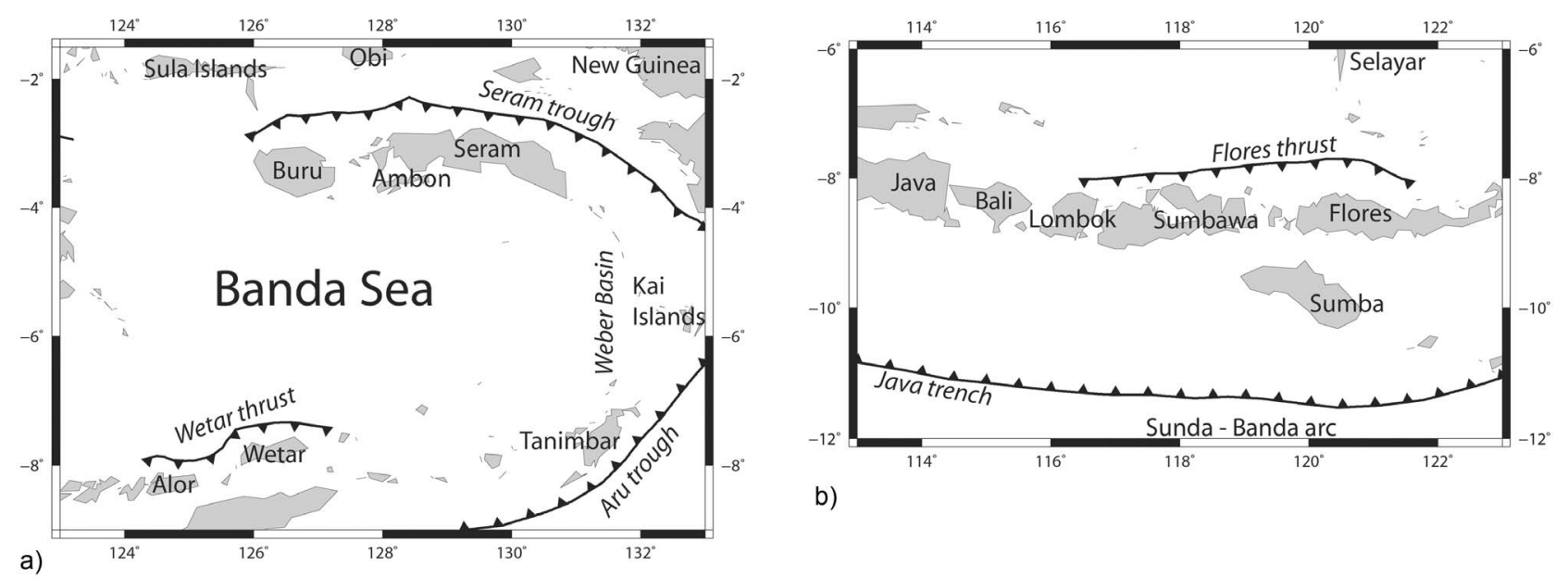

b)
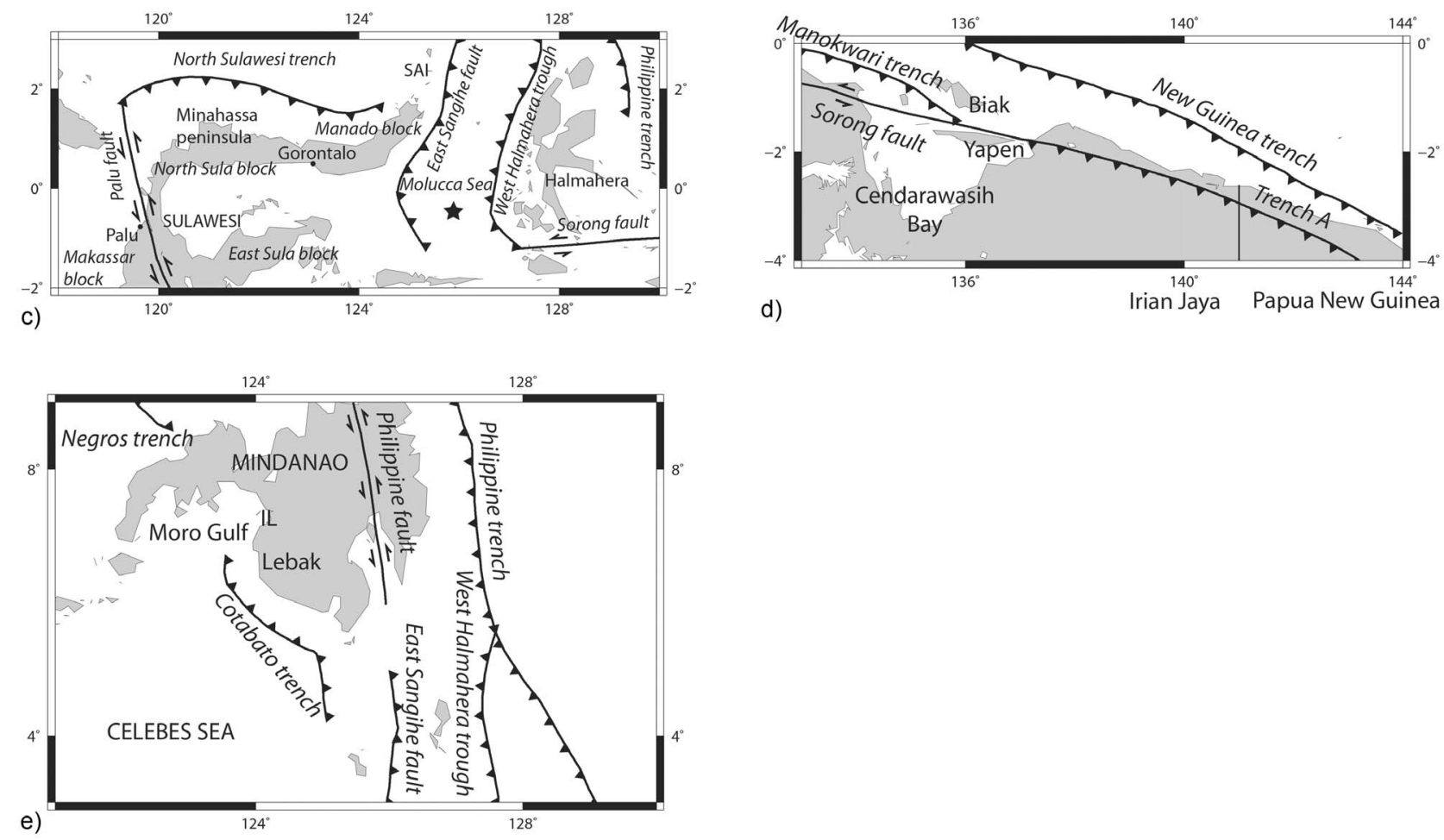

Figure 7. Detailed overview of tectonics and place names for the five sub-regions: (a) Banda Sea, (b) Bali/Flores, (c) northern Sulawesi and northern Moluccas (SAI: Sangihe Islands; star: location of the South East Asia triple junction as indicated by Walpersdorf et al. [1998]), (d) New Guinea, (e) southern Philippines (IL: Illana Bay).

larger than the largest historical event recorded in this region (1996 Biak Island).

\subsubsection{Southern Philippines}

[27] The Philippine earthquake on 16 August 1976 was, although very large $\left(\mathrm{M}_{\mathrm{w}} 8.1\right)$, not associated with the dominant tectonic feature of the Philippine trench, but with a less prominent trench system in the Moro Gulf (North Celebes Sea), the Cotabato trench. Since this event caused a locally destructive tsunami in 1976, this location was chosen for a scenario hindcasting this event (Figure 8). Due to the very diffuse seismicity in this region, the dip angle of the moment tensor for this special event was assumed representative for the area. The earthquake parameters are based on Stewart and Cohn [1979] and discussions with Emile Okal (personal communication, 2009), and tuned to match the tsunami runup distribution [Badillo and Astilla, 1978] in an iterative process including tsunami simulations and re-parameterization of the source. The upper edge of the fault planes follows the Cotabato trench as given by The Plates Project (http://www. ig.utexas.edu/research/prjects/plates/). On the east coast of Mindanao along the Philippine Trench subduction zone, several strong earthquakes of magnitudes up to $M_{w} 8.3$ are 


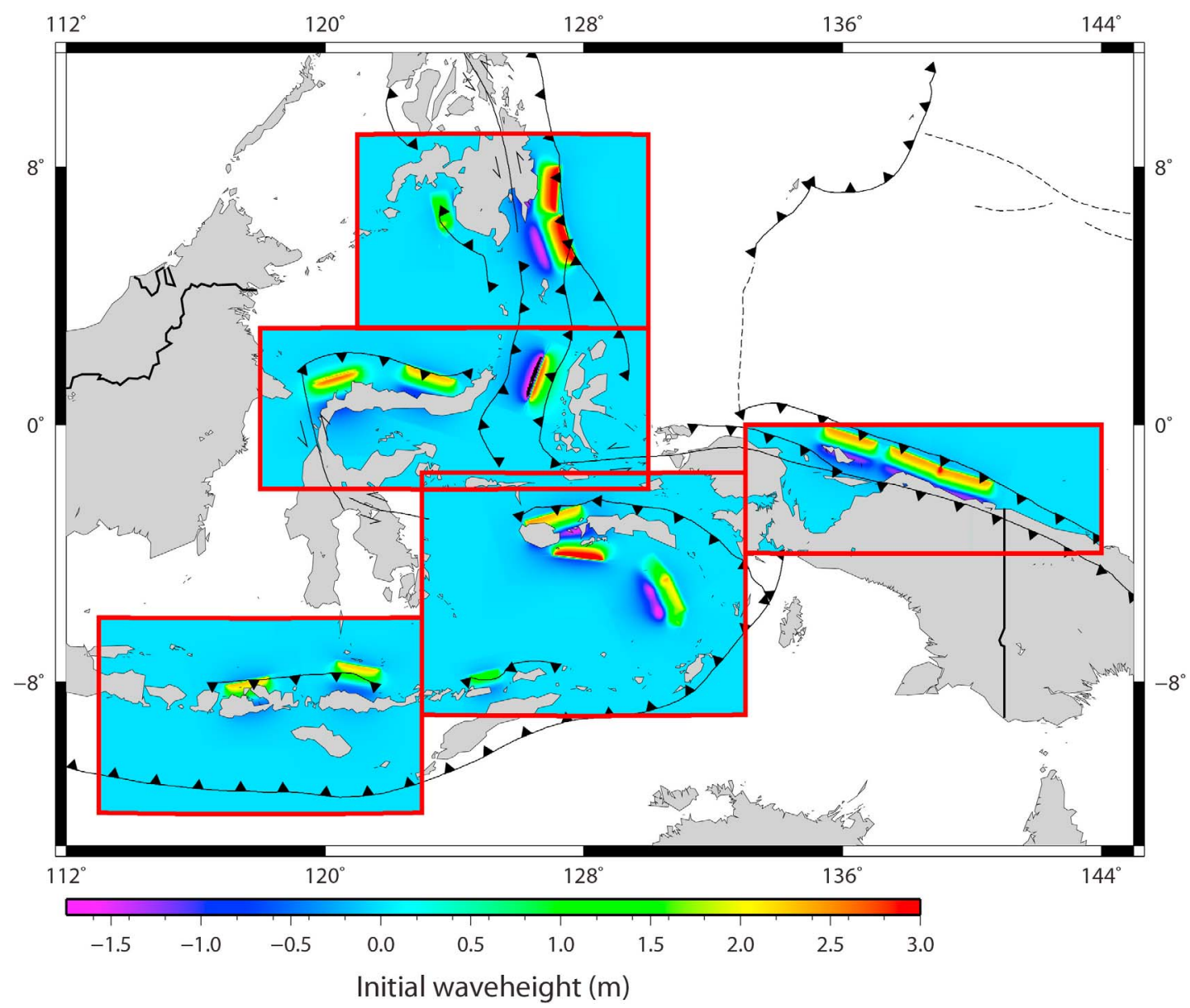

Figure 8. Location of scenarios in South East Asia with corresponding initial surface elevation (see color scale in meters). Black lines indicate major trenches, transform faults, and troughs. Note that several scenarios with different fault scaling have been computed for the eastern Philippines, though only one of those is visualized here.

present in historical catalogs such that the two $\mathrm{M}_{\mathrm{w}} 8.4$ scenarios provide worst-case scenarios for the eastern Mindanao coastlines (see Figure 7e for place names).

\section{Tsunami Simulations}

\subsection{Models for Tsunami Propagation and Wave Amplification}

[28] As already stated, the earthquake ruptures are considered as purely dip-slip faulting along a subduction zone with constant slip in dip direction, and the fault plane is extended to the surface (with some exceptions). The analytical formula of Okada [1985] is applied for computing the displacement of the seafloor, and the initial elevation of the seabed is copied to the sea surface and smoothed using a lowpass filter based on linear full potential theory along transects parallel to the dip [see Pedersen, 2001; Løvholt et al., 2012b].

[29] To compute tsunami propagation, a 'depth averaged three-dimensional model' (denoted a 2HD model, a model with two horizontal dimensions) is applied. The finite difference tsunami propagation model is based on the Boussinesq equations including higher order dispersion terms, Coriolis terms, and numerical hydrostatic correction terms. Boussinesq models capture both the effect of nonlinearity (steepening of the wavefront in shallower water) and dispersion (wavelength dependent wave speed). The operational Boussinesq tsunami model is labeled GloBouss and is formulated in both Cartesian and geographical coordinates [Pedersen and Løvholt, 2008; Løvholt et al., 2008, 2010]. For the open ocean tsunami propagation the public domain ETOPO 1 and 2 bathymetries (http://www.ngdc.noaa.gov/ $\mathrm{mgg} / \mathrm{fliers} / 01 \mathrm{mgg} 04 . \mathrm{html}$ ) are used with refinement for desired accuracy.

[30] For a regional study including hundreds of locations of interest, it is too time-consuming to perform refined numerical runup calculations for all scenarios and all locations. Moreover, required high resolution bathymetric and topographic data is lacking. In principle, data such as Shuttle Radar Topography Mission, SRTM (http://srtm.csi.cgiar. org) may be used, but they are inaccurate due artificially elevated land [see, e.g., Römer et al., 2012]. Therefore a faster, but still reliable procedure is used to transform offshore tsunami wave heights to maximum water levels by applying amplification factors. The amplification factors are obtained from lookup tables based on parameters describing the characteristics of the incident wave, the bathymetric slope, etc. The basis for the procedure is a large set of precomputed plane wave numerical simulations in idealized 

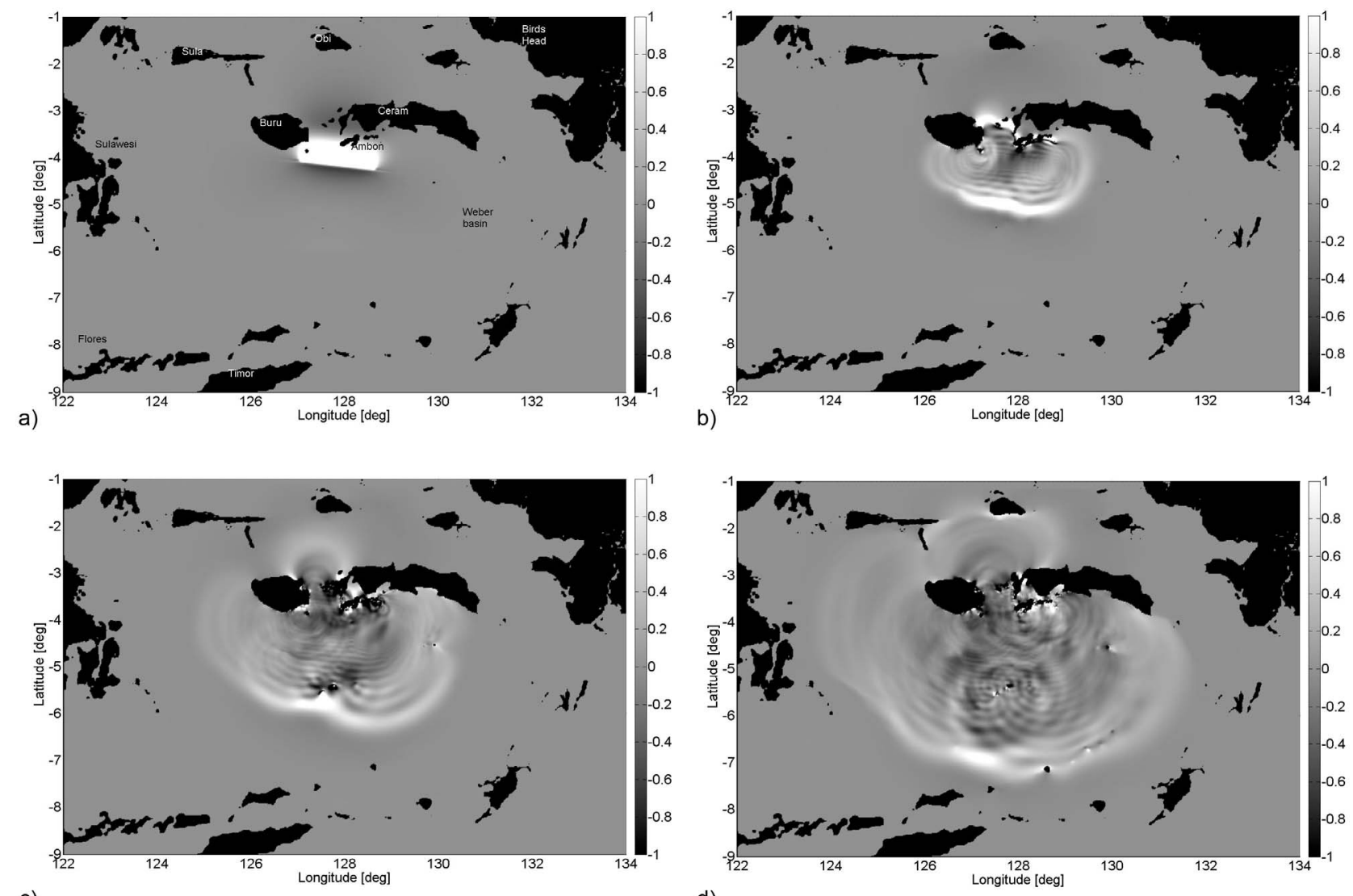

c)

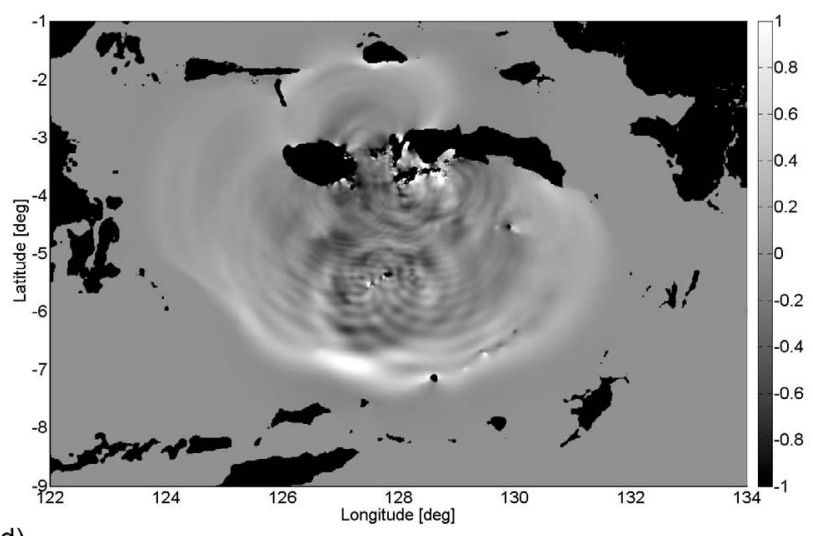

d)
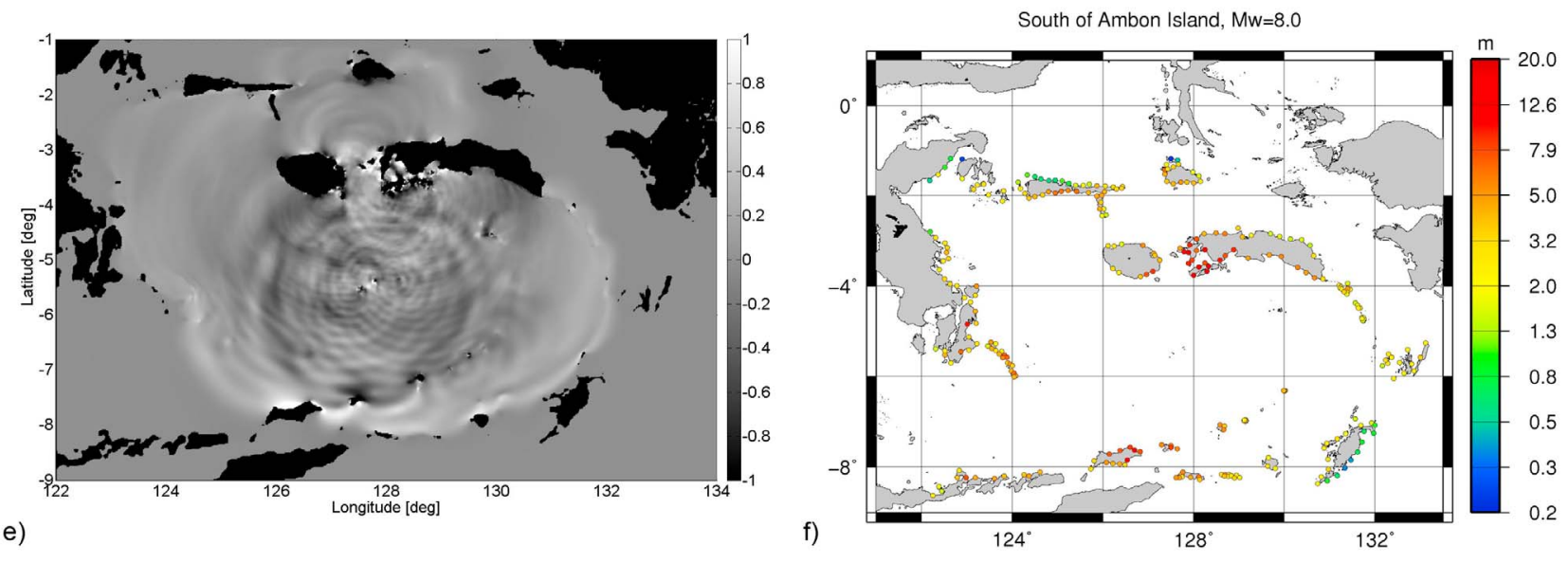

Figure 9. Tsunami simulation results for the $\mathrm{M}_{\mathrm{w}}$ 8.1 Ambon scenario, Banda Sea. (a) Initial surface elevation; (b-e) snapshots of the surface elevation after 10, 20, 30, and 40 min of propagation; (f) maximum water levels computed from amplification factors.

two dimensional (2D) transects with an incident sine shaped $\mathrm{N}$-wave as input. Parameters such as bathymetric profile, leading trough or leading peak, and wave period are varied. From the pre-computed numerical simulations, the amplification factors that relate the surface elevation at water depths of $50 \mathrm{~m}$ to the maximum water level are found (for further details, see Løvholt et al. [2012a]). Although the model does not include dry land inundation, the surface elevation on the boundary close to the shoreline (at $0.5 \mathrm{~m}$ water depth) with a no-flux condition yields a good approximation. For long non-breaking non-viscous waves, the linear solution for the maximum water level at the shoreline and the nonlinear solution for the maximum runup height on land are identical [Carrier and Greenspan, 1958]. Pedersen [2011] found that the linear solution works well also for oblique waves with incidence angles up to $70^{\circ}$, and that the occurrence of moderate angles of incidence $\left(\sim 45^{\circ}\right)$ reduces the runup only slightly. It is stressed that the maximum water level based on the method of amplification factors only gives a rough indication of the distribution of the maximum water level. For scenarios comparable with those addressed here, Løvholt et al. [2012a] found that the amplification factor method was 

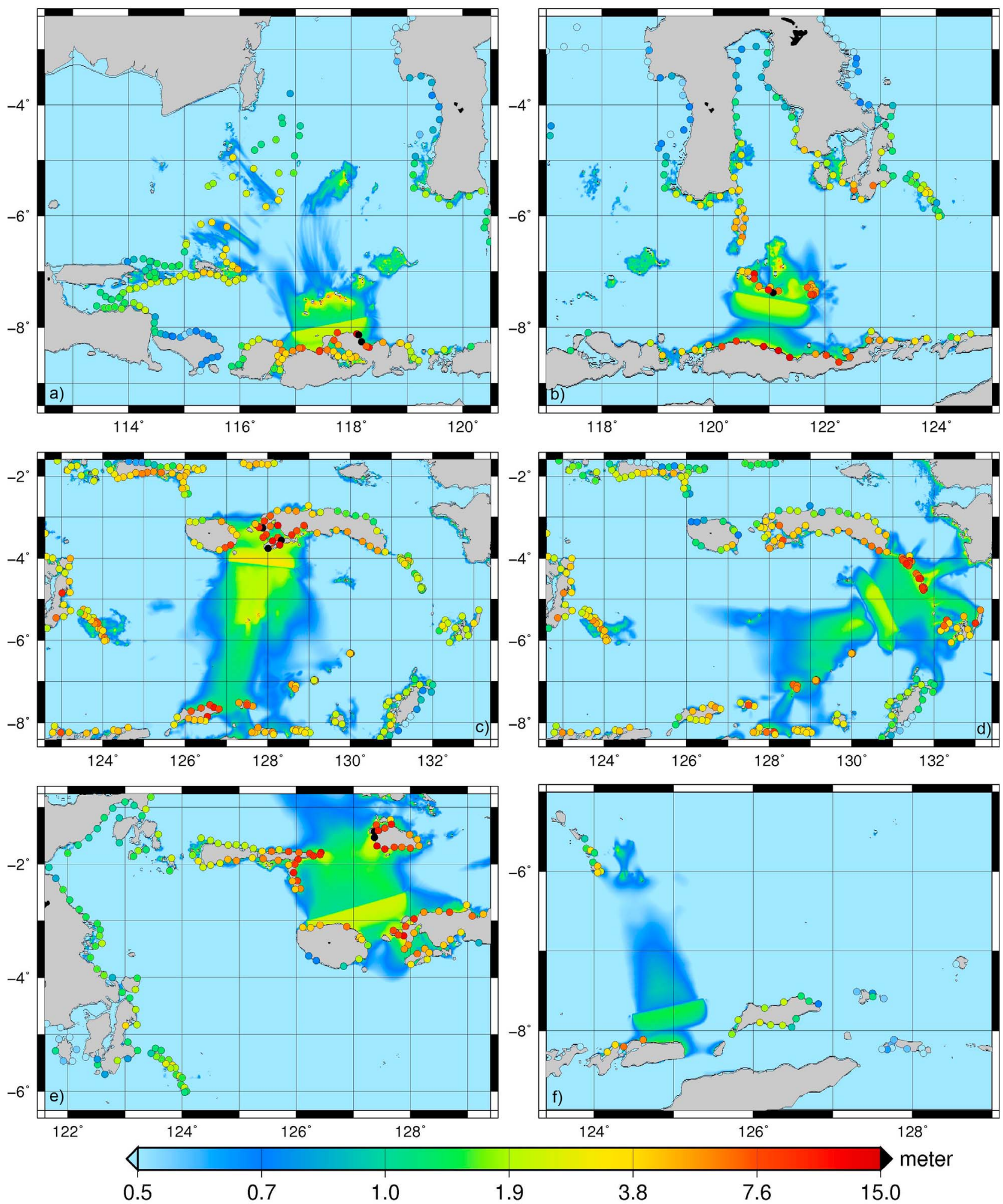

Figure 10. Maximum simulated tsunami surface elevation and water level for the (a, b) Bali and Flores and $(\mathrm{c}-\mathrm{f})$ Banda Sea scenarios illustrating the tsunami directivity.

slightly conservative compared to the operational inundation model ComMIT [Titov et al., 2011], typically yielding maximum water levels up to $20 \%$ higher than ComMIT. As the methodology is based on the plane wave assumption, three-dimensional (3D) effects such as refraction and focusing in e.g., bays and head lands are not captured.

[31] The procedure for calculating the maximum water levels is exemplified in Figure 9 for the $M_{w} 8.1$ Banda Sea scenario with source location south of Ambon Island. The 


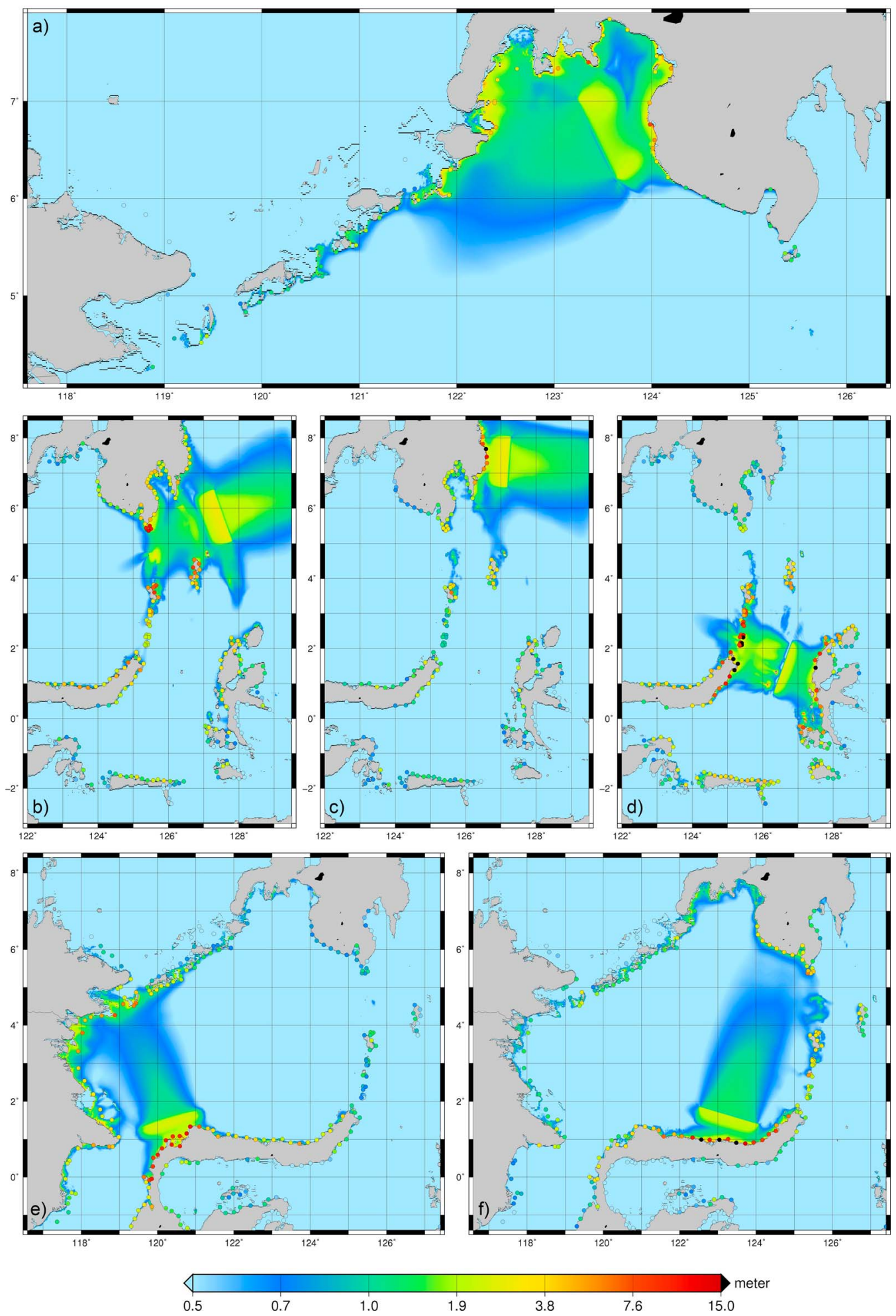

Figure 11. Maximum simulated tsunami surface elevation and water level for the (a) Cotabato scenario, $(b, c)$ the eastern Philippines scenarios, (d) the northern Moluccas scenario, and (e, f) the Northern Sulawesi scenarios.

initial water surface shown in the upper left panel displays a surface elevation in excess of $2 \mathrm{~m}$. The following snapshots show that all southern coastlines of the nearby islands of Buru, Seram, and Ambon are impacted within 20 min after rupture. After 40 min, the wave has crossed the Banda Sea; the coastlines of Flores, New Guinea, and Sulawesi are reached after one hour of propagation (not shown). Pronounced south-north directivity is displayed. Finally, 


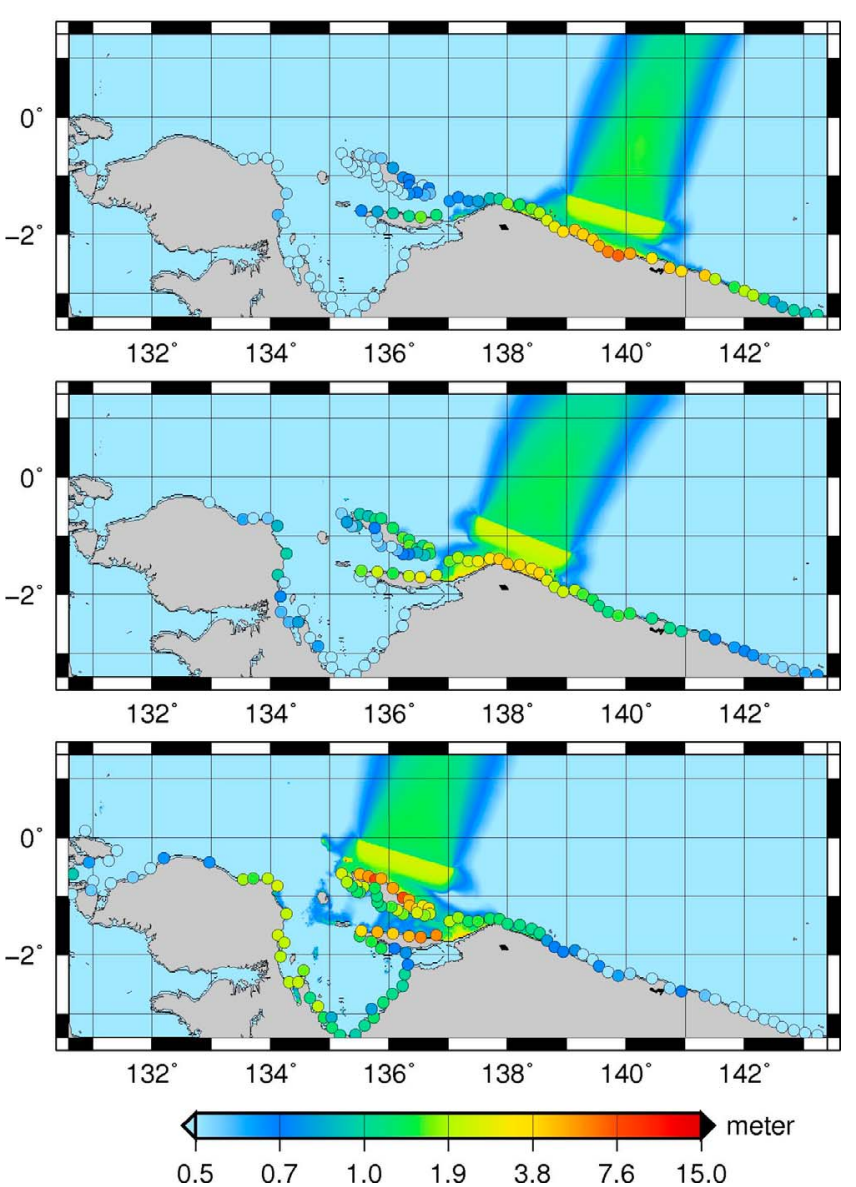

Figure 12. Maximum simulated tsunami surface elevation and water level for the New Guinea scenarios illustrating the tsunami directivity and maximum water levels.

Figure 9f displays the maximum water levels along the shoreline for this scenario, which are computed applying the pre-computed amplification factors to the maximum surface elevations at water depths of $50 \mathrm{~m}$ taken from the tsunami propagation model.

\subsection{Summary of Regional Tsunami Propagation Results}

\subsubsection{Banda Sea}

[32] The Banda Sea scenarios are examples of earthquakes that generate large tsunami runup in the near field, and still several meters of maximum water levels in the far field (Figure 10). The composite scenario situated in the eastern Weber Basin generates maximum water levels up to $10 \mathrm{~m}$ southeast of Seram, and 7-8 m along southwestern Seram (Figure 10d). This scenario has a pronounced east-west radiation pattern and will hence generate larger waves toward The Birds Head (Papua) and Sulawesi compared to the three other scenarios. Waves propagating eastward are subject to diffraction, which may increase maximum water levels locally on Papua. The scenario located south of Ambon gives maximum water levels ranging from $12-17 \mathrm{~m}$ at Ambon Island and Western Seram (Figure 10c). Even along the southern coastlines in the Banda Sea, the maximum water level may reach up to $7 \mathrm{~m}$, and $5 \mathrm{~m}$ as far west as Flores. Maximum water levels up to $5 \mathrm{~m}$ are also found north of Seram, and along the southwestern coastlines of Sulawesi. The scenario situated north of Buru and Seram Islands (Figure 10e) gives maximum water levels of $17 \mathrm{~m}$ at Obi and Sula Islands north of the source, and up to $10 \mathrm{~m}$ along the northern coastlines of the islands of Buru and Seram south of the source. The radiation is directed predominantly north-south, and hence the maximum water level is moderate in Sulawesi and Papua. With its smaller moment magnitude of 7.5, the Wetar thrust scenario displays more moderate water elevations than the other scenarios in this region (Figure 10f). Still, it may cause runup in the excess of $3-4 \mathrm{~m}$ in the near field. In the far-field, recognizable water levels up to $2-3 \mathrm{~m}$ are found.

4.2.2. Bali and Flores Seas

[33] The two $M_{w} 7.8$ tsunami scenarios both have a pronounced north-south directivity (see Figures 10a and 10b), and the simulations show that they may cause maximum water levels of 10-15 m most notably along the islands of Lombok, Sumbawa, and Flores. In addition, there are several smaller islands to the north that are severely affected with estimated maximum water levels in excess of $10 \mathrm{~m}$. Even further north, maximum water levels of $6 \mathrm{~m}$ are found along the Selayar Islands south of Sulawesi, whereas maximum water levels do not exceed $3 \mathrm{~m}$ along Sulawesi. Due to the extent and orientation of these scenarios, impact in westward and eastward directions is limited.

\subsubsection{Northern Sulawesi and Northern Moluccas}

[34] For both scenarios defined for northern Sulawesi, large maximum water levels ranging from 10-18 $\mathrm{m}$ are found immediately south of the source along the northern coastline of Sulawesi (Figures 11e and 11f). Moreover, both scenarios have the potential to generate significant runup on the opposite coastlines of the Celebes Sea. For the scenario situated northeast of the Minahassa peninsula, maximum water levels of 2-7 $\mathrm{m}$ arise in Borneo both along the Indonesian and Malaysian coastlines, whereas 2-3 m maximum water levels are found in the Makassar Strait south of Palu and on the Sulu Islands. For the scenario located north of Gorontalo, maximum water levels ranging from 2-4 $\mathrm{m}$ are found on the Sangihe Islands northeast of Sulawesi, and along the southern coastlines of Mindanao, the Philippines. For both scenarios, propagation eastward from the Sangihe Islands is limited due to the orientation of the sources, whereas propagation northward from the Sulu Islands is limited due to island reflections. The northern Moluccas scenario (Figure 11d) provides maximum water levels up to and above $15 \mathrm{~m}$ at certain points in the near field, i.e., along the coastlines of Halmahera and Sulawesi Islands facing the source. Due to the orientation of the source and its confinement between the surrounding islands, far field effects are moderate.

\subsubsection{New Guinea Region}

[35] For all three scenarios, large maximum water levels of up to 5-10 $\mathrm{m}$ are found along the northern coastline of New Guinea facing the New Guinea trench (Figure 12). The spatial extension of the largest maximum surface elevation is constrained locally for both the easterly scenarios, since the shoreline is more or less parallel to the source orientation. For the westernmost source, Biak, Yapen, and smaller 


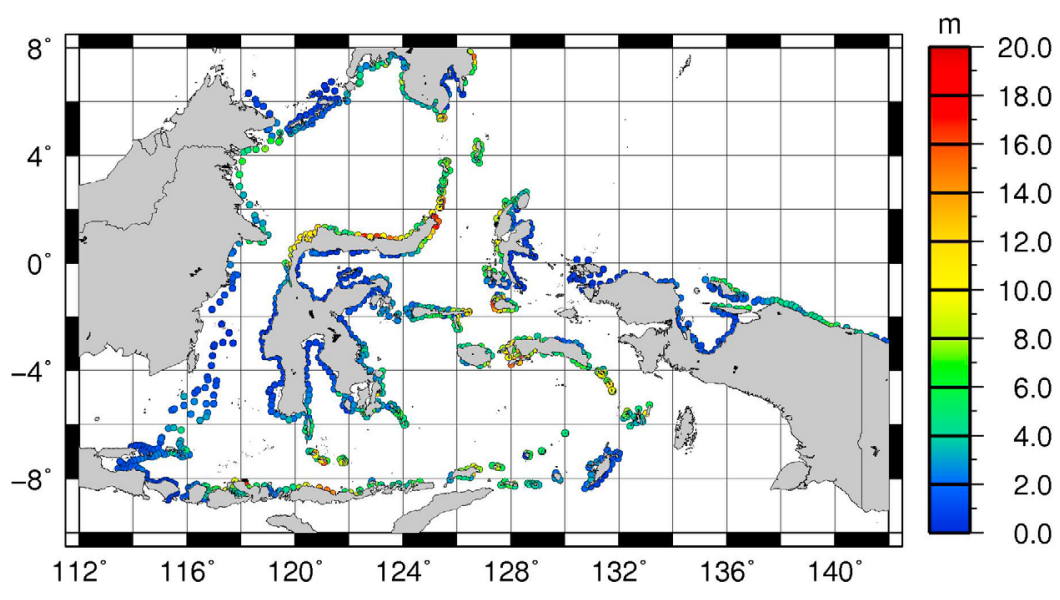

Figure 13. Merged tsunami hazard maps for eastern Indonesia and southern Philippines.

islands are partly shielding the coastlines of the Cenderawasih Bay east of The Birds Head.

\subsubsection{Southern Philippines}

[36] For the western Cotabato source, simulated maximum water levels of 3-5 m are found in Illana Bay (northeast of the source) and up to $8 \mathrm{~m}$ near Lebak south of Illana Bay (Figure 11a). Beyond the Moro Gulf, the simulated maximum water levels are lower than $2 \mathrm{~m}$. Both the maximum value and the distribution of the simulated maximum water levels are roughly consistent with reported runup heights from field surveys after the 1976 Moro Gulf tsunami [Badillo and Astilla, 1978] reporting a maximum runup of 9 $\mathrm{m}$ in the Lebak area and 3-6 $\mathrm{m}$ in Illana Bay. It is noted that preliminary simulations using the earthquake parameters of Stewart and Cohn [1979] provided smaller maximum water levels, and that a reduction in shear strength and corresponding increase in fault extensions and slip were necessary to fit the field observations better.

[37] The eastern Philippines scenarios (Figures $11 \mathrm{~b}$ and 11c) both provide large maximum water elevations exceeding $10 \mathrm{~m}$ locally. For the northerly scenario, the area close to the source has water levels ranging from 5-10 m. For the southerly scenario, maximum water levels up to $10 \mathrm{~m}$ are found only at the south tip of Mindanao Island, due to the source orientation toward southwest. On the other hand, the islands south of Mindanao are more influenced than the mainland as a consequence of the source directivity. The farfield effects of both scenarios are limited.

\subsection{Merged Hazard Results on a Regional Scale}

[38] In the following, the results presented for each region are merged in a manner suitable for a subsequent estimation of regional tsunami hazard. Using this approach, a single tsunami hazard map is obtained through a compilation of all maximum water levels for each of the individual tsunami scenarios (Figure 13).

[39] Simulated tsunami maximum water levels exceeding 2-4 $\mathrm{m}$ along the shorelines cover substantial parts of eastern Indonesia and the southern Philippines. Only a few areas seem to be effectively shielded from potential tsunamis. Moreover, it is stressed that in some areas, like eastern Halmahera and the Makassar Strait, the merged hazard map likely underestimates the hazard as our model there contains no local sources. In many regions, simulations indicate that shoreline maximum water levels may exceed $10 \mathrm{~m}$ locally and even reach above $20 \mathrm{~m}$ in the immediate vicinity of the tsunamigenic source. This indicates shoreline maximum water levels within the same order of magnitude as simulated forecasts [e.g., Gayer et al., 2010] for worst-case scenarios along the Sumatra trench toward the much studied cities of Padang and Cilacap. For sections of coastlines close to the sources, a tsunami may strike only a few minutes after it is generated, providing little time for warning and putting numerous densely populated areas at high risk.

\section{Concluding Remarks}

[40] The tsunami hazard in eastern Indonesia and the southern Philippines is analyzed through 'credible worstcase scenarios' covering the major tsunamigenic fault zones of the study region. To a large extent, the scenario locations mimic those of the historical events in the region, and in this sense the weight is on 'credible' more than on 'worst-case'. Possible events of smaller probability of occurrence are not considered, but the results clearly demonstrate that the scenarios here are sufficiently alarming. The simulations show that large parts of the coastlines are exposed to maximum water levels in the excess of 2-4 m, sometimes even exceeding $10 \mathrm{~m}$. It must be noted that although the simulated maximum water levels indicate a severe threat, the tsunami metric (maximum water level) must be combined with the temporal probability of the scenario to quantify the hazard. To this end, the scenario magnitudes were compared with documented regional seismicity as well as activity rates inferred from tectonic convergence rates to obtain an order of magnitude estimate for earthquake return periods giving a range of roughly 100 to 1000 years. The hazard evaluations given here are admittedly of first order, particularly given the tectonic complexity of this region.

[41] Most likely only the Sumatra and Java trenches provide the potential for generating megathrust earthquakes and associated major (transoceanic) tsunamis in this region. Still, the frequency of reported historical tsunamis of destructive power is equally high in the less studied areas north of the Java trench. Similarly, order of magnitude estimates of return periods resulting from this study roughly compare with similar estimates along the Sumatra Trench [e.g., Borrero et al., 2006; Sengara et al., 2008]. The propagation 
times for the coastlines in question are rarely more than one hour even in the far-field. Moreover, several of the affected areas are highly populated. The combination of large inundation potential, short warning times, and relatively short return periods strongly suggest that the tsunami hazard in these regions is alarming; this may also indicate that the risk is unacceptably high. This calls for immediate and concerted actions aimed at mitigating the tsunami risk.

[42] Acknowledgments. The present article emerges from work carried out for the project "Tsunami Risk Assessment and mitigation in S\&SE Asia - Phase 2" funded by the Norwegian Ministry of Foreign Affairs (NMFA). We thank the NMFA, NORSAR, and NGI for providing the funding leading to this paper. The project was considered as an extension of a Phase 1 project toward Thailand. We thank Kjell Karlsrud and Bjørn Kalsnes for the project management. Further, the authors would like to thank the Coordinating Committee for Geoscience Programmes in East and Southeast Asia (CCOP) for leading the "Phase 2" project. We also thank the collaborating partners in PHIVOLCS (Philippine Institute of Volcanology and Seismology, Manila) and CVGHM (Center of Volcanology and Geological Hazard Mitigation, Bandung) for providing technical information and assistance related to the interpretation of historical tsunami events. We thank Roger Musson for providing us with his latest algorithm for maximum-likelihood recurrence rate calculation, and Steven Gibbons for reviewing the English grammar. Finally, we thank three anonymous reviewers for their valuable comments.

\section{References}

Ammon, C. J., et al. (2005), Rupture process of the 2004 Sumatra-Andaman earthquake, Science, 308, 1133-1139, doi:10.1126/science.1112260.

Ammon, C. J., H. Kanamori, T. Lay, and A. A. Velasco (2006), The 17 July 2006 Java tsunami earthquake, Geophys. Res. Lett., 33, L24308, doi:10.1029/2006GL028005.

Annaka, T., K. Satake, T. Sakakiyama, K. Yanagisawa, and N. Shuto (2007), Logic-tree approach for probabilistic tsunami hazard analysis and its applications to the Japanese coasts, Pure Appl. Geophys., 164, 577-592, doi:10.1007/s00024-006-0174-3.

Badillo, V. L., and Z. C. Astilla (1978), Moro Gulf tsunami of 17. Augus 1976, report, Philipp. Inst. of Volcanol. and Seismol., Quezon City, Philippines

Bardet, J.-P., C. Synolakis, H. Davis, F. Imamura, and E. Okal (2003) Landslide tsunamis: Recent findings and research directions, Pure Appl. Geophys., 160, 1793-1809, doi:10.1007/s00024-003-2406-0.

Behrens, J., A. Androsov, A. Y. Babeyko, S. Harig, F. Klaschka, and L. Mentrup (2010), A new multi-sensor approach to simulation assisted tsunami early warning, Nat. Hazards Earth Syst. Sci., 10, 1085-1100, doi:10.5194/nhess-10-1085-2010.

Bernard, E. N., H. O. Mofjeld, V. V. Titov, C. E. Synolakis, and F. I. González (2006), Tsunami: Scientific frontiers, mitigation, forecasting, and policy implications, Philos. Trans. R. Soc. A, 364(1845), 1989-2007, doi:10.1098/rsta.2006.1809.

Bilek, S., and E. R. Engdahl (2007), Rupture characterization and aftershock relocations for the 1994 and 2006 tsunami earthquakes in the Java subduction zone, Geophys. Res. Lett., 34, L20311, doi:10.1029/ 2007GL031357.

Bird, P. (2003), An updated digital model of plate boundaries, Geochem. Geophys. Geosyst., 4(3), 1027, doi:10.1029/2001GC000252.

Blaser, L., F. Krüger, M. Ohrnberger, and F. Scherbaum (2010), Scaling relations of earthquake source parameter estimates with special focus on subduction environment, Bull. Seismol. Soc. Am., 100, 2914-2926, doi:10.1785/0120100111.

Blaser, L., M. Ohrnberger, F. Krüger, and F. Scherbaum (2012), Probabilistic tsunami threat assessment of 10 recent earthquakes offshore Sumatra Geophys. J. Int., 188, 1273-1284, doi:10.1111/j.1365-246X.2011.05324.x.

Borrero, J., K. Sieh, M. Chlieh, and C. E. Synolakis (2006), Tsunami inundation modelling for western Sumatra, Proc Natl. Acad. Sci. U. S. A., 103(52), 19673-19677.

Breen, N. A., and E. A. Silver (1989), The Wetar back arc thrust belt, eastern Indonesia: The effect of accretion against an irregularly shaped arc, Tectonophysics, 8(1), 85-98.

Brune, S., A. Y. Babeyko, S. Ladage, and S. V. Sobolev (2010), Landslide tsunami hazard in the Indonesian Sunda Arc, Nat. Hazards Earth Syst Sci., 10, 589-604, doi:10.5194/nhess-10-589-2010.

Cardwell, R. K., and B. L. Isacks (1978), Geometry of the subducted lithosphere beneath the Banda Sea in eastern Indonesia from seismicity and fault plane solutions, J. Geophys. Res., 83, 2825-2838, doi:10.1029/ JB083iB06p02825.

Cardwell, R. K., E. S. Kappel, M. S. Lawrence, and B. L. Isacks (1981), Plate convergence along the Indonesian arc, Eos Trans. AGU, 62, 404.

Carrier, G. F., and H. P. Greenspan (1958), Water waves of finite amplitude on a sloping beach, J. Fluid Mech., 4, 97-109, doi:10.1017/S0022112058000331.

Engdahl, E. R, and A. Villaseñor (2002), Global Seismicity: 1900-1999, in International Handbook of Earthquake and Engineering Seismology, vol. 81A, pp. 665-690, Academic, Amsterdam.

Engdahl, E. R., A. Villaseñor, H. R. DeShon, and C. H. Thurber (2007) Teleseismic relocation and assessment of seismicity (1918-2005) in the region of the $2004 \mathrm{Mw} 9.0$ Sumatra-Andaman and $2005 \mathrm{Mw} 8.6 \mathrm{Nias}$ Island great earthquakes, Bull. Seismol. Soc. Am., 97(1A), S43-S61, doi:10.1785/0120050614.

Falck, C., M. Ramatschi, C. Subarya, M. Bartsch, A. Merx, J. Hoeberechts, and G. Schmidt (2010), Near real-time GPS applications for tsunami early warning systems, Nat. Hazards Earth Syst. Sci., 10, 181-189, doi:10.5194/nhess-10-181-2010.

Fujii, Y., and K. Satake (2006), Source of the July 2006 West Java tsunami estimated from tide gauge records, Geophys. Res. Lett., 33, L24317, doi:10.1029/2006GL028049.

Gayer, G., S. Leschka, I. Nöhren, O. Larsen, and H. Günther (2010), Tsunami inundation modelling based on detailed roughness maps of densely populated areas, Nat. Hazards Earth Syst. Sci., 10, 1679-1687, doi:10.5194/nhess-10-1679-2010.

Geist, E., and T. Parsons (2006), Probabilistic analysis of tsunami hazards, Nat. Hazards, 37, 277-314, doi:10.1007/s11069-005-4646-z.

González, F. I., et al. (2009), Probabilistic tsunami hazard assessment at Seaside, Oregon, for near- and far-field seismic sources, J. Geophys. Res., 114, C11023, doi:10.1029/2008JC005132.

Hamilton, W. B. (1979), Tectonics of the Indonesian region, U.S. Geol. Surv. Prof. Pap. 1078, 345 pp.

Hamzah, L., N. T. Puspito, and F. Imamura (2000), Tsunami catalog and zones in Indonesia, J. Nat. Disaster Sci., 22, 25-43, doi:10.2328/ jnds. 22.25 .

Hanks, T. C., and H. Kanamori (1979), A moment magnitude scale, J. Geophys. Res., 84, 2348-2350, doi:10.1029/JB084iB05p02348.

Harbitz, C. B., S. Glimsdal, S. Bazin, N. Zamora, F. Løvholt, H. Bungum, H. Smebye, P. Gauer, and O. Kjekstad (2012), Tsunami hazard in the Caribbean: Regional exposure derived from credible worst case scenarios, Cont. Shelf Res., 8, 1-23, doi:10.1016/j.csr.2012.02.006.

Heinrich, P., A. Piatanesi, E. A. Okal, and H. Hebert (2000), Near-field modeling of the July 17, 1998 tsunami in Papua New Guinea, Geophys. Res. Lett., 27, 3037-3040, doi:10.1029/2000GL011497.

Imamura, F., and K. Hashi (2003), Re-examination of the tsunami source of the 1998 Papua New Guinea earthquake tsunami, Pure Appl. Geophys., 160, 2071-2086, doi:10.1007/s00024-003-2420-2.

Imamura, F., C. E. Synolakis, E. Gica, V. V. Titov, E. Listanco, and H. J. Lee (1995), Field survey of the 1994 Mindoro Island, Philippines tsunami, Pure Appl. Geophys., 144(3-4), 875-890, doi:10.1007/BF00874399.

Jankaew, K., B. F. Atwater, Y. Sawai, M. Choowong, T. Charoentitirat M. E. Martin, and A. Prendergast (2008), Medieval forewarning of the 2004 Indian Ocean tsunami in Thailand, Nature, 455, 1228-1231, doi: $10.1038 /$ nature 07373 .

Kaiser, G., L. Scheele, A. Kortenhaus, F. Løvholt, H. Römer, and S. Leschka (2011), The influence of land cover roughness on the results of high resolution tsunami inundation modeling, Nat. Hazards Earth Syst. Sci., 11 2521-2540, doi:10.5194/nhess-11-2521-2011.

Katili, J. A. (1989), Review of past and present geotectonic concepts of Eastern Indonesia, Neth. J. Sea Res., 24(2-3), 103-129, doi:10.1016/ 0077-7579(89)90143-9.

Kreemer, C., W. E. Holt, S. Goes, and R. Govers (2000), Active deformation in eastern Indonesia and the Philippines from GPS and seismicity data, J. Geophys. Res., 105(B1), 663-680, doi:10.1029/1999JB900356.

Lauterjung, J., U. Münch, and A. Rudloff (2010), The challenge of installing a tsunami early warning system in the vicinity of the Sunda Arc, Indonesia, Nat. Hazards Earth Syst. Sci., 10, 641-646, doi:10.5194/nhess-10641-2010

Lay, T., et al. (2005), The great Sumatra-Andaman earthquake of December 26, 2004, Science, 308, 1127-1133, doi:10.1126/science.1112250.

Leonard, M. (2010), Earthquake fault scaling: Self-consistent relating of rupture length, width, average displacement, and moment release, Bull. Seismol. Soc. Am., 100, 1971-1988, doi:10.1785/0120090189.

Lorito, S., M. M. Tiberti, R. Basili, A. Piatanesi, and G. Valensise (2008), Earthquake-generated tsunamis in the Mediterranean Sea: Scenarios of potential threats to Southern Italy, J. Geophys. Res., 113, B01301, doi:10.1029/2007JB004943.

Løvholt, F., H. Bungum, C. B. Harbitz, S. Glimsdal, C. D. Lindholm, and G. Pedersen (2006), Earthquake related tsunami hazard along the western 
coast of Thailand, Nat. Hazards Earth Syst. Sci., 6, 979-997, doi:10.5194/nhess-6-979-2006.

Løvholt, F., G. Pedersen, and G. Gisler (2008), Oceanic propagation of a potential tsunami from the La Palma Island, J. Geophys. Res., 113, C09026, doi:10.1029/2007JC004603.

Løvholt, F., G. Pedersen, and S. Glimsdal (2010), Coupling of dispersive tsunami propagation and shallow water coastal response, Open Oceanogr. $J ., 4,71-82$

Løvholt, F., S. Glimsdal, C. B. Harbitz, N. Zamora, F. Nadim, P. Peduzzi, H. Dao, and H. Smebye (2012a), Tsunami hazard and exposure on the global scale, Earth Sci. Rev., 110(1-4), 58-73, doi:10.1016/j.earscirev.2011.10.002.

Løvholt, F., G. Pedersen, S. Bazin, D. Kühn, R. E. Bredesen, and C. Harbitz (2012b), Stochastic analysis of tsunami runup due to heterogeneous coseismic slip and dispersion, J. Geophys. Res., 117, C03047, doi:10.1029/2011JC007616.

Matsutomi, H., N. Shuto, F. Imamura, and T. Takahashi (2001), Field survey of the 1996 Irian Jaya earthquake tsunami in Biak Island, Nat Hazards, 24(3), 199-212, doi:10.1023/A:1012042222880.

McCaffrey, R. (1982), Lithospheric deformation within the Molucca Sea arc-arc collision: Evidence from shallow and intermediate earthquake activity, J. Geophys. Res., 87(B5), 3663-3678, doi:10.1029/ JB087iB05p03663.

McCaffrey, R. (1988), Active tectonics of the eastern Sunda and Banda arcs, J. Geophys. Res., 93(B12), 15,163-15,182, doi:10.1029/ JB093iB12p15163.

McCaffrey, R., and J. Nábělek (1984), The geometry of back arc thrusting along the Eastern Sunda arc, Indonesia: Constraints from earthquake and gravity data, J. Geophys. Res., 89(B7), 6171-6179, doi:10.1029/ JB089iB07p06171.

McCaffrey, R., and J. Nábĕlek (1987), Earthquakes, gravity, and the origin of the Bali Basin: An example of a nascent continental fold-and-thrus belt, J. Geophys. Res., 92(B1), 441-460, doi:10.1029/JB092iB01p00441.

McCaffrey, R., P. Molnar, S. W. Roecker, and Y. S. Joyodiwiryo (1985), Microearthquake seismicity and fault plane solutions related to arc-continent collision in the eastern Sunda arc, Indonesia, J. Geophys. Res., 90, 4511-4528, doi:10.1029/JB090iB06p04511.

McCloskey, J., A. Antonioli, A. Piatanesi, K. Sieh, S. Steacy, S. Nalbant M. Cocco, C. Giuchi, J. Huang, and P. Dunlop (2008), Tsunami threat in the Indian Ocean from a future megathrust earthquake west of Sumatra Earth Planet. Sci. Lett., 265, 61-81, doi:10.1016/j.epsl.2007.09.034.

McCloskey, J., D. Lange, F. Tilmann, S. S. Nalbant, A. F. Bell, D. H. Natawidjaja, and A. Rietbrock (2010), The September 2009 Padang earthquake, Nat. Geosci., 3, 70-71, doi:10.1038/ngeo753.

Monecke, K., W. Finger, D. Klarer, W. Kongko, B. G. McAdoo, A. L. Moore, and S. U. Sudrajat (2008), A 1,000-year sediment record of tsunami recurrence in northern Sumatra, Nature, 455, 1232-1234, doi:10.1038/nature 07374

Musson, R. M. W. (2011), Assessment of activity rates for seismic source zones, report, 23 pp., Seismic Hazard Harmonization in Eur., Zürich, Switzerland

Musson, R. M. W., J. Wössner, L. Danciu, H. Bungum, and R. Basili (2011), Activity rates for seismic source, report, 32 pp., Seismic Hazard Harmonization in Eur., Zürich, Switzerland

Nadim, F., and T. Glade (2006), On tsunami risk assessment for the west coast of Thailand, in Geohazards, edited by F. Nadim et al., pp. 1-15, Eng. Conf. Int., Lillehammer, Norway. [Available at http://services. bepress.com/eci/geohazards/28.]

Natawidjaja, D. H., K. Sieh, M. Chlieh, J. Galetzka, B. W. Suwargadi, H. Cheng, R. L. Edwards, J.-P. Avouac, and S. N. Ward (2006), Source parameters of the great Sumatran megathrust earthquakes of 1797 and 1833 inferred from coral microatolls, J. Geophys. Res., 111, B06403, doi:10.1029/2005JB004025

Nugroho, H., R. Harris, A. W. Lestariya, and B. Maruf (2009), Plate boundary reorganization in the active Banda Arc-continent collision: Insights from new GPS measurements, Tectonophysics, 479, 52-65, doi:10.1016/j.tecto.2009.01.026.

Okada, Y. (1985), Surface deformation due to shear and tensile faults in a half-space, Bull. Seismol. Soc. Am., 74(4), 1135-1154.

Okal, E. A., and D. Reymond (2003), The mechanism of great Banda Sea earthquake of 1 February 1938: Applying the method of preliminary determination of focal mechanism to a historical event, Earth Planet. Sci. Lett., 216, 1-15, doi:10.1016/S0012-821X(03)00475-8.

Okal, E. A., and B. A. Romanowicz (1994), On the variation of b-values with earthquake size, Phys. Earth Planet. Inter., 87(1-2), 55-76, doi:10.1016/0031-9201(94)90021-3.

Okal, E. A., and C. E. Synolakis (2004), Source discriminants for near-field tsunamis, Geophys. J. Int., 158, 899-912, doi:10.1111/j.1365246X.2004.02347.x
Okal, E. A., and C. E. Synolakis (2008), Far-field tsunami hazard from mega-thrust earthquakes in the Indian Ocean, Geophys. J. Int., 172 , 995-1015, doi:10.1111/j.1365-246X.2007.03674.x.

Okal, E. A., J. C. Borrero, and C. E. Synolakis (2006), Evaluation of tsunami risk from regional earthquakes at Pisco, Peru, Bull. Seismol. Soc. Am., 96(5), 1634-1648, doi:10.1785/0120050158.

Okal, E. A., C. E. Synolakis, and N. Kalligeris (2011), Tsunami simulations for regional sources in the South China and adjoining seas, Pure Appl. Geophys., 168, 1153-1173, doi:10.1007/s00024-010-0230-x.

Ortiz, M., and R. Bilham (2003), Source area and rupture parameters of the 31 December $1881 \mathrm{Mw}=7.9 \mathrm{Car}$ Nicobar earthquake estimated from tsunamis recorded in the Bay of Bengal, J. Geophys. Res., 108(B4), 2215, doi:10.1029/2002JB001941.

Pedersen, G. (2001), A Note on Tsunami Generation by Earthquakes, Ser. Appl. Math., vol. 4, Dep. of Math., Univ. of Oslo, Oslo, Norway.

Pedersen, G. (2011), Oblique runup of non-breaking solitary waves on an inclined plane, J. Fluid Mech., 668, 582-606, doi:10.1017/ S0022112010005343.

Pedersen, G., and F. Løvholt (2008), Documentation of a Global Boussinesq Solver, Ser. Appl. Math., vol. 1, Dep. of Math., Univ. of Oslo, Oslo, Norway.

Pelinovsky, E., D. Yuliadi, G. Prasetya, and R. Hidayat (1997), The 1996 Sulawesi tsunami, Nat. Hazards, 16, 29-38, doi:10.1023/A:1007904610680.

Post, J., S. Wegscheider, M. Mück, K. Zosseder, R. Kiefl, T. Steinmetz, an G. Strunz (2009), Assessment of human immediate response capability related to tsunami threats in Indonesia at a sub-national scale, Nat. Hazards Earth Syst. Sci., 9, 1075-1086, doi:10.5194/nhess-9-1075-2009.

Römer, H., G. Kaiser, H. Sterr, and R. Ludwig (2010), Using remote sensing to assess tsunami-induced impacts on coastal forest ecosystems at the Andaman Sea coast of Thailand, Nat. Hazards Earth Syst. Sci. 10, 729-745, doi:10.5194/nhess-10-729-2010.

Römer, H., P. Willroth, G. Kaiser, A. T. Vafeidis, R. Ludwig, H. Sterr, and J. Revilla Diez (2012), Potential of remote sensing techniques for tsunami hazard and vulnerability analysis-a case study from Phang-Nga province, Thailand, Nat. Hazards Earth Syst. Sci., 12, 2103-2126.

Roessler, D., F. Krueger, M. Ohrnberger, and L. Ehlert (2010), Rapid characterization of large earthquakes by multiple seismic broadband arrays Nat. Hazards Earth Syst. Sci., 10, 923-932, doi:10.5194/nhess-10-9232010

Rudloff, A., J. Lauterjung, U. Münch, and S. Tinti (2009), Preface "The GITEWS Project (German-Indonesian Tsunami Early Warning System)", Nat. Hazards Earth Syst. Sci., 9, 1381-1382, doi:10.5194/nhess-9-13812009.

Satake, K., and B. F. Atwater (2007), Long-term perspectives on giant earthquakes and tsunamis at subduction zones, Annu. Rev. Earth Planet. Sci., 35, 349-374, doi:10.1146/annurev.earth.35.031306.140302.

Sengara, I. W., H. Latief, and S. B. Kusuma (2008), Probabilistic seismic and tsunami hazard analysis for design criteria and disaster mitigation in rehabilitation and reconstruction of a coastal area in city of Banda Aceh, in Geotechnical Engineering for Disaster Mitigation and Rehabilitation, edited by H.-L. Liu, A. Deng, and J. Chu, pp. 224-230, Springer, New York

Socquet, A., W. Simons, C. Vigny, R. McCaffrey, C. Subarya, D. Sarsito, B. Ambrosius, and W. Spakman (2006), Microblock rotations and fault coupling in SE Asia triple junction (Sulawesi, Indonesia) from GPS and earthquake slip vector data, J. Geophys. Res., 111, B08409, doi:10.1029/ 2005JB003963.

Spahn, H., M. Hoppe, H. D. Vidiarina, and B. Usdianto (2010), Experience from three years of local capacity development for tsunami early warning in Indonesia: Challenges, lessons and the way ahead, Nat. Hazards Earth Syst. Sci., 10, 1411-1429, doi:10.5194/nhess-10-1411-2010.

Stein, S., and E. A. Okal (2007), Ultralong period seismic study of the December 2004 Indian Ocean earthquake and implications for regional tectonics and the subduction process, Bull. Seismol. Soc. Am., 97(1A), S279-S295, doi:10.1785/0120050617.

Stewart, G. S., and S. N. Cohn (1979), The 1976 August 16, Mindanao, Philippine earthquake (MS =7.8)-evidence for a subduction zone south of Mindanao, Geophys. J. R. Astron. Soc., 57, 51-65, doi:10.1111/ j.1365-246X.1979.tb03771.x.

Tang, L., V. V. Titov, and C. D. Chamberlin (2009), Development, testing, and applications of site-specific tsunami inundation models for real-time forecasting, J. Geophys. Res., 114, C12025, doi:10.1029/2009JC005476.

Tappin, D. R., P. Watts, and S. T. Grilli (2008), The Papua New Guinea tsunami of 17 July 1998: Anatomy of a catastrophic event, Nat. Hazards Earth Syst. Sci., 8, 243-266, doi:10.5194/nhess-8-243-2008.

Thio, H. K., P. Sommerville, and G. Ichinose (2007), Probabilistic analysis of strong ground motion and tsunami hazards in Southeast Asia, paper presented at NUS-TMSI Workshop, Natl. Univ. of Singapore, Singapore, 7-9 Mar. 
Tinti, S., and A. Armigliato (2003), The use of scenarios to evaluate the tsunami impact in southern Italy, Mar. Geol., 199(3-4), 221-243, doi:10.1016/S0025-3227(03)00192-0.

Tinti, S., F. Zaniboni, G. Pagnoni, and A. Manucci (2008), Stromboli Island (Italy): Scenarios of tsunamis generated by submarine landslides, Pure Appl. Geophys., 165(11-12), 2143-2167, doi:10.1007/s00024-008$0420-\mathrm{y}$.

Titov, V. V., H. O. Mofjeld, F. I. González, and J. C. Newman (2001), Offshore forecasting of Alaska tsunamis in Hawaii, in Tsunami Research at the End of a Critical Decade, edited by G. T. Hebenstreit, pp. 75-90, Kluwer Acad., Dordrecht, Netherlands.

Titov, V. V., A. B. Rabinovich, H. O. Mofjeld, R. E. Thomson, and F. I. González (2005), The global reach of the 26 December 2004 Sumatra Tsunami, Science, 309, 2045-2048, doi:10.1126/science.1114576.

Titov, V. V., C. W. Moore, D. J. M. Greenslade, C. Pattiaratchi, R. Badal, C. E. Synolakis, and U. Kânoğlu (2011), A new tool for inundation modeling: Community Modeling Interface for Tsunamis (ComMIT), Pure Appl. Geophys., 168, 2121-2131, doi:10.1007/s00024-011-0292-4.

Tsuji, Y., F. Imamura, H. Matsumoto, C. Synolakis, P. T. Nanang, Jumaidi, S. Harada, S. S. Han, K. Arai, and B. Cook (1995), Field Survey of the
East Java Earthquake and Tsunami of June 3, 1994, Pure Appl. Geophys., 144(3-4), 840-854.

Vigny, C., et al. (2002), Migration of seismicity and earthquake interactions monitored by GPS in SE Asia triple junction: Sulawesi, Indonesia, J. Geophys. Res., 107(B10), 2231, doi:10.1029/2001JB000377.

Villaseñor, A., and E. R. Engdahl (2007), Systematic relocation of early instrumental seismicity: Earthquakes in the international seismological summary for 1960-1963, Bull. Seismol. Soc. Am., 97(6), 1820-1832, doi:10.1785/0120060118

Walpersdorf, A., C. Vigny, P. Namurung, C. Subarya, and S. Sutisna (1998), Determining the Sula block kinematics in the triple junction area in Indonesia by GPS, Geophys. J. Int., 135(2), 351-361, doi:10.1046/ j.1365-246X.1998.00641.x.

Wells, D. L., and K. J. Coppersmith (1994), New empirical relationships among magnitude, rupture length, rupture width, rupture area, and surface displacement, Bull. Seismol. Soc. Am., 84(4), 974-1002.

Yeh, H., F. Imamura, C. Synolakis, Y. Tsuji, P. L. F. Liu, and S. Shi (1995), The Flores Island tsunamis, Eos Trans. AGU, 74(33), 371-373. 